\title{
The transport history of two Saharan dust events archived in an Alpine ice core
}

\author{
H. Sodemann ${ }^{1}$, A. S. Palmer ${ }^{2,}$, C. Schwierz ${ }^{1}$, M. Schwikowski ${ }^{2}$, and H. Wernli ${ }^{1,3}$ \\ ${ }^{1}$ Institute for Atmospheric and Climate Science, ETH Zurich, Switzerland \\ ${ }^{2}$ Paul Scherrer Institute, Villigen, Switzerland \\ ${ }^{3}$ Institute for Atmospheric Physics, University of Mainz, Germany \\ *now at: University of Tasmania, Tasmania, Australia
}

Received: 6 July 2005 - Published in Atmos. Chem. Phys. Discuss.: 26 August 2005

Revised: 5 December 2005 - Accepted: 17 January 2006 - Published: 28 February 2006

\begin{abstract}
Mineral dust from the Saharan desert can be transported across the Mediterranean towards the Alpine region several times a year. When coinciding with snowfall, the dust can be deposited on Alpine glaciers and then appears as yellow or red layers in ice cores. Two such significant dust events were identified in an ice core drilled at the highaccumulation site Piz Zupó in the Swiss Alps $\left(46^{\circ} 22^{\prime} \mathrm{N}\right.$, $9^{\circ} 55^{\prime} \mathrm{E}, 3850 \mathrm{~m}$ a.s.1.). From stable oxygen isotopes and major ion concentrations, the events were approximately dated as October and March 2000. In order to link the dust record in the ice core to the meteorological situation that led to the dust events, a novel methodology based on back-trajectory analysis was developed. It allowed the detailed analysis of the specific meteorologic flow evolution that was associated with Saharan dust transport into the Alps, and the identification of dust sources, atmospheric transport paths, and wet deposition periods for both dust events. Differences in the chemical signature of the two dust events were interpreted with respect to contributions from the dust sources and aerosol scavenging during the transport.

For the October event, the trajectory analysis indicated that dust deposition took place during 13-15 October 2000. Mobilisation areas of dust were mainly identified in the Algerian and Libyan deserts. A combination of an upper-level potential vorticity streamer and a midlevel jet across Algeria first brought moist Atlantic air and later mixed air from the tropics and Saharan desert across the Mediterranean towards the Alps. The March event consisted of two different deposition phases which took place during 17-19 and 23-25 March 2000. The first phase was associated with an exceptional transport pathway past Iceland and towards the Alps from northerly directions. The second phase was similar to the October event. A significant peak of methanesulphonic
\end{abstract}

Correspondence to: H. Sodemann

(harald.sodemann@env.ethz.ch) acid associated with the March dust event was most likely caused by incorporation of biogenic aerosol while passing through the marine boundary layer of the western Mediterranean during a local phytoplankton bloom. From this study, we conclude that for a detailed understanding of the chemical signal recorded in dust events at Piz Zupó, it is essential to consider the whole transport sequence of mineral aerosol, consisting of dust mobilisation, transport, and deposition at the glacier.

\section{Introduction}

Dust plays a significant role in the global climate system. It influences the radiative properties of the atmosphere, plays a complex role in cloud formation, and is an important source of nutrients in biogeochemical cycles (Prospero and Lamb, 2003). The Saharan desert is the most important natural source of dust (Goudie and Middleton, 2001). Frequently, Saharan dust is ejected into the Mediterranean atmosphere (Moulin et al., 1998). In some instances, Saharan dust has been transported as far as northern Scandinavia (Franzén et al., 1995). More commonly, Saharan dust may reach central Europe and in particular the Alpine region up to several times a year. Prodi and Fea $(1978,1979)$ inferred Saharan dust events in the Italian Alps from air filter samples, and identified typical synoptic situations which are associated with this dust transport pathway.

Precipitation that contains scavenged Saharan dust is known as "red rain" or "yellow snow" in some areas. Along with the colour, the dust load strongly imprints upon the precipitation chemistry. Several investigations focused on the identification of the source areas of dust from these chemical characteristics. By analysing "red rain" in northeastern Spain, Avila et al. (1997) detected differences in the

Published by Copernicus GmbH on behalf of the European Geosciences Union. 
mineralogical and soluble ion chemistry composition for different source regions in northern Africa. During a large Saharan dust event in the Alps, Schwikowski et al. (1995) found characteristic mass concentrations of dust-related ions in aerosol and precipitation samples to be consistent with mineralogical indicators and back-trajectories. At higher elevation sites, scavenged Saharan dust may be deposited as snow, buried as distinct layers in firn and ultimately preserved in glaciers. Wagenbach and Geis (1989) used this fact to identify Saharan dust events in an ice core retrieved from a glacier in the Swiss Alps. Hence, given that the age of the ice can be determined accurately, ice cores can be used as an archive of such Saharan dust events. Conversely, if the characteristics of a particular Saharan dust event are known in detail, it can be used as a reference horizon for the dating of other Alpine ice cores.

The chemical composition of the mineral aerosol can differ largely between individual dust events. Usually, these differences are attributed to characteristics of the various mobilisation areas of dust (Bergametti et al., 1989; Avila et al., 1997; Claquin et al., 1999). However, a dust plume may also be chemically altered during its transport to the deposition site, for example by the uptake of predominantly marine compounds such as sodium $\left(\mathrm{Na}^{+}\right)$and chloride $\left(\mathrm{Cl}^{-}\right)$over the ocean (Schwikowski et al., 1995), or by predominantly anthropogenic pollutants, such as ammonium $\left(\mathrm{NH}_{4}^{+}\right)$, residing in the boundary layer (BL) (Jones et al., 2003). Other aerosols, such as the exclusively marine biogenic compound methanesulphonic acid ( $\left.\mathrm{MSA}, \mathrm{CH}_{3} \mathrm{SO}_{3} \mathrm{H}\right)$ may even provide information on ocean-atmosphere interaction. It therefore may be essential to consider the complete transport history of dust-laden air parcels to gain a detailed understanding of the chemical signal of a specific dust event in the ice core. This comprises three distinct stages in the life cycle of a dust event, namely dust mobilisation at the source area, dust transport according to the specific meteorological situation, and finally dust deposition at the observation site. All three of these stages are characterised by specific meteorological conditions and processes.

In this study, we reconstruct the transport history of two large dust events which were recorded in an ice core drilled at Piz Zupó in the Swiss Alps. The ice core section attributed to the year 2000 shows two pronounced episodes of enhanced concentrations of dust tracers (e.g. $\mathrm{Ca}^{2+}$ ). We interpret the chemical signatures of these two dust events by means of an extended back-trajectory analysis. Our investigation focuses on two main questions:

(i) What influences the dust origin, transport pathway and deposition of a chemical signal recorded in an ice core? In other words, are differences in the chemical signal for different dust events due to a differing dust origin, transport or deposition process - or a combination thereof?

(ii) Is there an archetypal meteorological flow evolution that leads to Saharan dust transport to the Alps, or can dif- ferent types of meteorological events in principle lead to similar dust signals in Alpine ice cores?

A common way to address these two questions are backward trajectories. Back-trajectory analysis has been used as a tool for studying the transport history of dust in a number of studies (e.g. Schwikowski et al., 1995; Avila et al., 1997; Collaud Coen et al., 2004; Bonasoni et al., 2004; Barkan et al., 2005; Papayannis et al., 2005). Most of these studies, however, inferred dust source regions directly from the horizontal position of an air parcel several days before arrival, without taking into account its vertical position or any further information. Here, we propose a new methodology which is based on back-trajectories, yet in addition makes use of meteorological information along the air parcels' flight paths. By means of objective criteria, locations are extracted where dust mobilisation, chemical interaction, and wet deposition are likely to occur during dust transport. This enhanced backtrajectory method provides a closer link between (i) the meteorological processes leading to mobilisation, transport, and deposition of a dust plume, and (ii) the chemical signal at the deposition site, than would be possible with the use of backward trajectories alone. This approach can be considered as a first step towards explicit Lagrangian dust transport modelling.

With this study, we aim to enhance the understanding of the chemical fingerprints left in the ice core by specific meteorological processes. Today's high-quality meteorological data and satellite observations provide an ideal opportunity to investigate how recent Saharan dust events become preserved in an ice core. Ultimately, a better understanding of the relevant processes could provide important keys on how to interpret whole ice core records as archives of the frequency and amplitudes of past Saharan dust events.

\section{Data}

\subsection{Ice core site and analysis}

In March 2002, a $43 \mathrm{~m}$ long ice core, corresponding to $29 \mathrm{~m}$ water equivalent (w.e.), was retrieved from the high-altitude site Piz Zupó ( $46^{\circ} 22^{\prime}$ N, $9^{\circ} 55^{\prime}$ E, $3850 \mathrm{~m}$ a.s.1.) in the Swiss Alps (Fig. 1). The drilling site was located on the saddle between Piz Zupó and Piz Argient, and was exposed to advection from north-westerly and south-easterly directions. Despite being on a saddle, with $2.6 \pm 0.8 \mathrm{~m}$ w.e. for the time period 1992-2001 the mean annual accumulation rate at the drilling location is rather high (Palmer et al., 2006 ${ }^{1}$, see also Sect. 3). Mean annual precipitation from nearby lower-elevation meteorological stations is much lower $(0.93-$ $1.20 \mathrm{~m}$ ) for the same period of time, while the year-to-year

\footnotetext{
${ }^{1}$ Palmer, A. S., Jenk, T., Schwikowski, M., Saurer, M., Schwerzmann, A., Lüthi, M., Funk, M., and Gäggeler, H. W.: A new ice core record from Piz Zupó, South-East Switzerland, in preparation, 2006.
} 


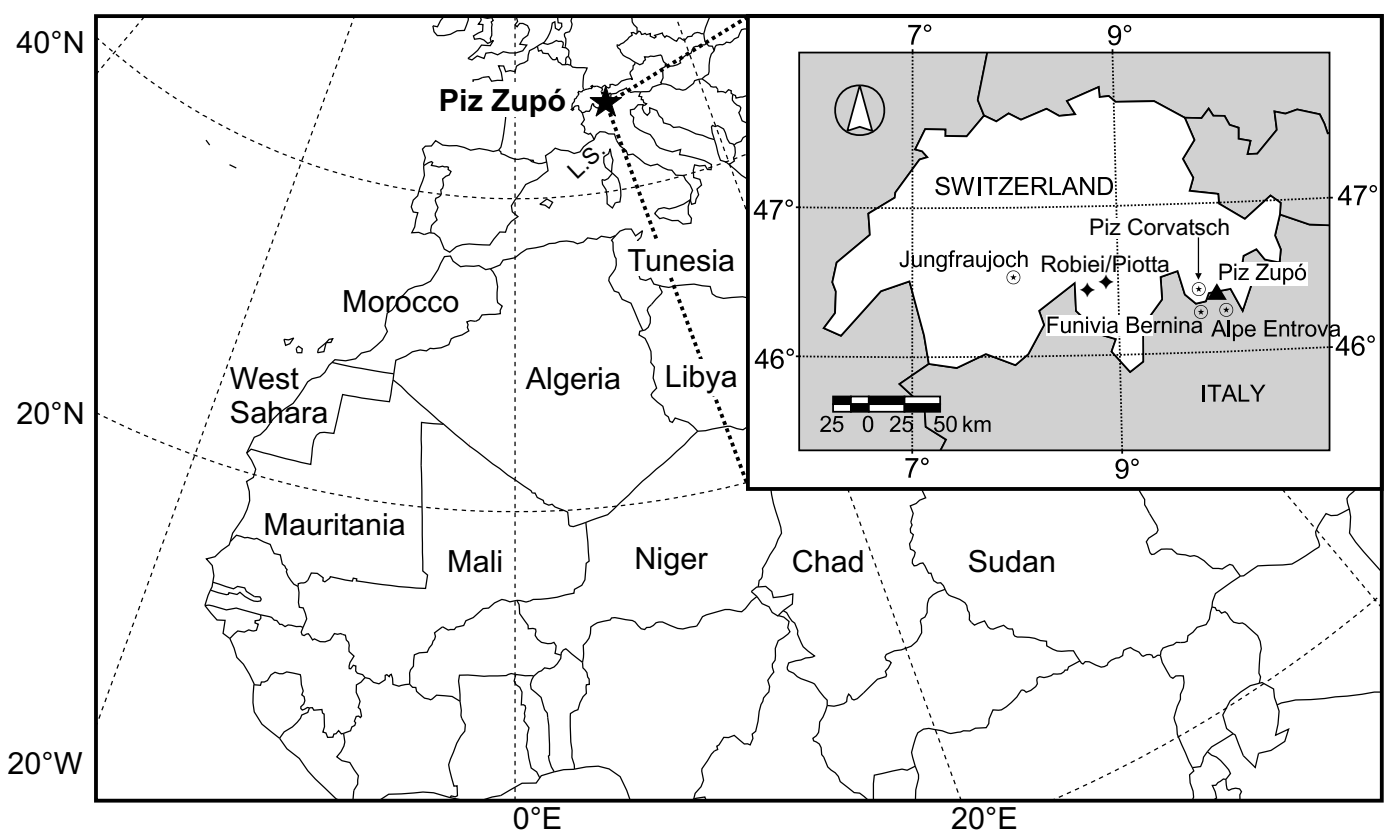

Fig. 1. Geographical map of the countries containing parts of the Saharan desert. Inset shows the location of the ice core site (Piz Zupó), the aerosol measurement site (Jungfraujoch), two stations where precipitation chemistry is analysed at irregular intervals (Robiei, Piotta), and three precipitation stations near Piz Zupó (Piz Corvatsch, Funivia Bernina, Alpe Entrova). The Ligurian Sea is denoted by L. S.

variations agree well. This fact together with the high accumulation rate at the ice core site indicates that wind erosion is not significant at the drilling site.

The ice core was examined in the freezer $\left(-20^{\circ} \mathrm{C}\right)$ at the Paul Scherrer Institute prior to decontamination procedures. Length, diameter, density and visual features (dust layers and ice lenses) of the individual core sections were noted. Ice core sections were then cut into $4-5 \mathrm{~cm}$ sections using established techniques (Eichler et al., 2000).

The samples were analysed for a suite of anions and cations $\left(\mathrm{F}^{-}, \mathrm{CH}_{3} \mathrm{COO}^{-}, \mathrm{CHOO}^{-}, \mathrm{MSA}, \mathrm{Cl}^{-}, \mathrm{NO}_{3}^{-}, \mathrm{SO}_{4}^{2-}\right.$, $\mathrm{C}_{2} \mathrm{O}_{4}^{2-}, \mathrm{Na}^{+}, \mathrm{NH}_{4}^{+}, \mathrm{K}^{+}, \mathrm{Mg}^{2+}, \mathrm{Ca}^{2+}$ ) using ion chromatography (IC). Cations were measured using a $16 \mathrm{~min}$ isocratic method with $20 \mathrm{mM}$ MSA eluent at $1 \mathrm{~mL} \mathrm{~min}^{-1}$. Anions were analysed in 19 min method involving gradient elution (concentrations between 0.25 to $24 \mathrm{mM} \mathrm{NaOH}$ ) at $0.5 \mathrm{~mL} \mathrm{~min}^{-1}$. Suppressed conductivity detection was used in both IC methods. Measurement of the oxygen isotope ratio, $\delta^{18} \mathrm{O}$ (defined as the relative deviation of the ${ }^{18} \mathrm{O} /{ }^{16} \mathrm{O}$ ratio of the sample from the international standard VSMOW) at Paul Scherrer Institute involved the pyrolysis of water to $\mathrm{CO}$ at $1450^{\circ} \mathrm{C}$ in a glassy carbon reactor (Saurer et al., 1998; Kornexyl et al., 1999), and subsequent mass-spectrometric analysis of ${ }^{12} \mathrm{C}^{16} \mathrm{O}$ and ${ }^{12} \mathrm{C}^{18} \mathrm{O}$ (Delta Plus XL, Finnigan MAT, Bremen, Germany). A complete description of the procedures used for decontamination, analysis and dating of the Piz Zupó ice core are given in Palmer et al. (2006).

\subsection{Precipitation data}

Precipitation data from three automated weather stations located in the vicinity of Piz Zupó were used as observational indicators of wet deposition at the glacier site (Fig. 1). The Swiss station Piz Corvatsch ( $46^{\circ} 25^{\prime}$ N, $9^{\circ} 49^{\prime}$ E, 3015 m a.s.l.) is located on a ridge $\sim 10 \mathrm{~km}$ northwest of Piz Zupó and $\sim 800 \mathrm{~m}$ lower than the ice-core drilling site. At this altitude, reliable precipitation measurements are difficult due to frequent snowfall, and some rain shadowing during southerly flow may occur. Still, with respect to timing and intensity, the precipitation registered here should compare reasonably with the precipitation at Piz Zupó itself. The two stations P41 and P42 are located at Alpe Entrova (1905 m a.s.1.) and Funivia Bernina (2014 $\mathrm{m}$ a.s.1.), respectively, on the southern (Italian) slope of the Bernina massif. These weather stations are likely to be influenced by orographic shadowing and congestion, and hence can show different precipitation magnitudes and timings to Piz Zupó, depending on the flow direction. All half-hourly precipitation data were aggregated into $6 \mathrm{~h}$ periods centered around 00Z, 06Z, 12Z, and 18Z for better comparison with the other meteorological data.

\subsection{Satellite imagery}

The concentration of chlorophyll $a$ (chlo- $a$ ) at the sea surface is a proxy for the biogenic contribution to organic aerosol in the marine BL (O'Dowd et al., 2004), which via oxidative processes also includes MSA (Huebert et al., 2004). Hence, 
in this study we used composite Sea-viewing Wide Field-ofview Sensor (SeaWiFS) chlo- $a$ products processed with the OC4v4 algorithm. The OC4 algorithm version 4 was proposed by O'Reilly et al. (1998). It provides the combined chlo- $a$ and pheophytin $a$ concentrations from an empirical relation to the maximum remote-sensing reflectance ratio at the sea surface with respect to several selected wavelengths.

One-week composites of chlo- $a$ averaged over the periods 07-14 October and 13-20 March 2000 were acquired from the SeaWiFS Project Homepage (see http://oceancolor.gsfc. nasa.gov/cgi/level3.pl). Gaps in the weekly composite maps due to clouds were filled with the respective monthly mean values. The OC4v4 algorithm is known to systematically overestimate chlo- $a$ concentrations in oligotrophic areas in the Mediterranean (Bosc et al., 2004). Therefore, we applied the regional bio-optical algorithm proposed by Bricaud et al. (2002) to the chlo- $a$ maps of both periods, which by means of an empirical relationship decreases OC4v4 chlorophyll $a$ concentrations below $0.4 \mathrm{mg} \mathrm{m}^{-3}$ by a factor of up to 2.5 .

In addition, visible SeaWiFS imagery was acquired for the visual identification of dust plumes leaving the African continent. Finally, half-hourly Meteosat infrared (IR) imagery processed by MeteoSwiss were used for the inspection of cloud patterns and potential precipitation areas during the two study periods.

\subsection{Meteorological data}

ERA-40 reanalysis data (Simmons and Gibson, 2000) from the European Centre for Medium-range Weather Forecast (ECMWF) were the basis of the meteorological analysis and the back-trajectory calculations. The data were used on the original model levels and interpolated onto a regular grid at $1^{\circ} \times 1^{\circ}$ resolution. Considered primary variables include horizontal and vertical wind velocities, temperature, and specific humidity. From these quantities, secondary variables like sea level pressure, potential temperature and potential vorticity were calculated.

The meteorological situation determining the transport of dust parcels was examined from time series of maps of various meteorological fields. Upper-level potential vorticity (PV) on the $320 \mathrm{~K}$ isentropic surface was used to identify the larger-scale synoptic situation. Horizontal wind velocities at 200 and $500 \mathrm{hPa}$ served to highlight influences of upper-level jets on dust mobilisation and transport. Also considered were the vertically averaged horizontal moisture flux

$$
F=\frac{1}{p_{s}-p_{t}} \int_{p_{t}}^{p_{s}} q \cdot|\boldsymbol{v}| d p
$$

(with $q$ being the mixing ratio in $\mathrm{g} \mathrm{kg}^{-1}, \boldsymbol{v}$ the horizontal wind vector) between pressure level $p_{t}=700 \mathrm{hPa}$ and the surface $\left(p_{s}\right)$, and wind vectors at $700 \mathrm{hPa}$. Finally, sea level pressure (SLP) and equivalent potential temperature $\left(\theta_{e}\right)$ at $850 \mathrm{hPa}$ allowed identification of the synoptic situation and airmass differences at lower levels. Vertical cross-sections of these meteorological fields together with the positions of the identified dust trajectories were useful to investigate potential interactions between dust clouds and the marine BL at selected times.

\section{Ice core chemistry of dust events}

Dating the ice core by annual layer counting was started at the surface which corresponds to the date of drilling (March 2002), making the attribution of the year 2000 relatively straightforward. The ice core's $\delta^{18} \mathrm{O}$ and chemical records, in particular $\mathrm{NH}_{4}^{+}$, show clear seasonal variations with high values during summer and low values in winter, allowing for annual dating of the core (Eichler et al., 2000; Preunkert et al., 2000). This dating implied that the Piz Zupó ice core spans the time period 1991-2001 ( $\pm 1 \mathrm{yr})$. The relatively large annual accumulation ( $2.6 \mathrm{~m}$ w.e.) allowed for a high resolution analysis of the ice core chemistry. The sampling scheme was chosen to provide at least 12 samples per accumulation year. In the case of the core section described here, a much higher resolution due to the high accumulation rate results. As the section ascribed to the year 2000 consists of about 100 samples, the time resolution per sample probably ranges between several hours to weeks, depending on the frequency and intensity of precipitation events at the site.

Initial study of the Piz Zupó record for the year 2000 showed two large $\mathrm{Ca}^{2+}$ peaks, typical indicators of mineral dust transport to the site (Fig. 2). A number of smaller excursions in the $\mathrm{Ca}^{2+}$ record were observed between the two large events, but are not further examined here.

The first (later) large dust event was located at a depth of 4.5-4.7 $\mathrm{m}$ w.e. in the ice core and had high concentrations of $\mathrm{Na}^{+}, \mathrm{K}^{+}, \mathrm{Mg}^{2+}, \mathrm{Ca}^{2+}, \mathrm{Cl}^{-}$and $\mathrm{SO}_{4}^{2-}$. This event shows virtually no MSA and low concentrations of $\mathrm{NH}_{4}^{+}$and $\mathrm{NO}_{3}^{-}$. The isotopic and chemical signatures before and after this event were characteristic of early winter conditions following the decrease of anthropogenic input in summer (Eichler et al., 2000; Preunkert et al., 2000). Yellow/brown particles were observed in the ice samples for this section of the core. There are three reports of dust deposition in Southern Switzerland during 13-15 October 2000. (1) Observation of "red rain" in the Ticino region on 13 October (personal communication from G. Kappenberger, 2002). (2) Abnormally high levels of $\mathrm{Ca}^{2+}, \mathrm{CO}_{3}^{2-}, \mathrm{Cl}^{-}, \mathrm{Na}^{+}, \mathrm{K}^{+}, \mathrm{SO}_{4}^{2-}$ and $\mathrm{Mg}^{2+}$ in weekly bulk wet-deposition samples from the Swiss precipitation measurement stations Robiei $\left(46^{\circ} 27^{\prime} \mathrm{N}, 8^{\circ} 31^{\prime} \mathrm{E}\right)$ and Piotta $\left(46^{\circ} 31^{\prime} \mathrm{N}, 8^{\circ} 41^{\prime} \mathrm{E}\right)$ for the period 9-15 October (personal communication from M. Veronesi, 2002). (3) Observation of yellow snowfall on the Basodino glacier (120 km W of Piz Zupó, $46^{\circ} 25^{\prime} \mathrm{N}, 8^{\circ} 29^{\prime}$ E) for the period 13-15 October 2000 (personal communication from G. Kappenberger). Therefore, the first dust event visible in the ice core most probably took place around 15 October 2000. 


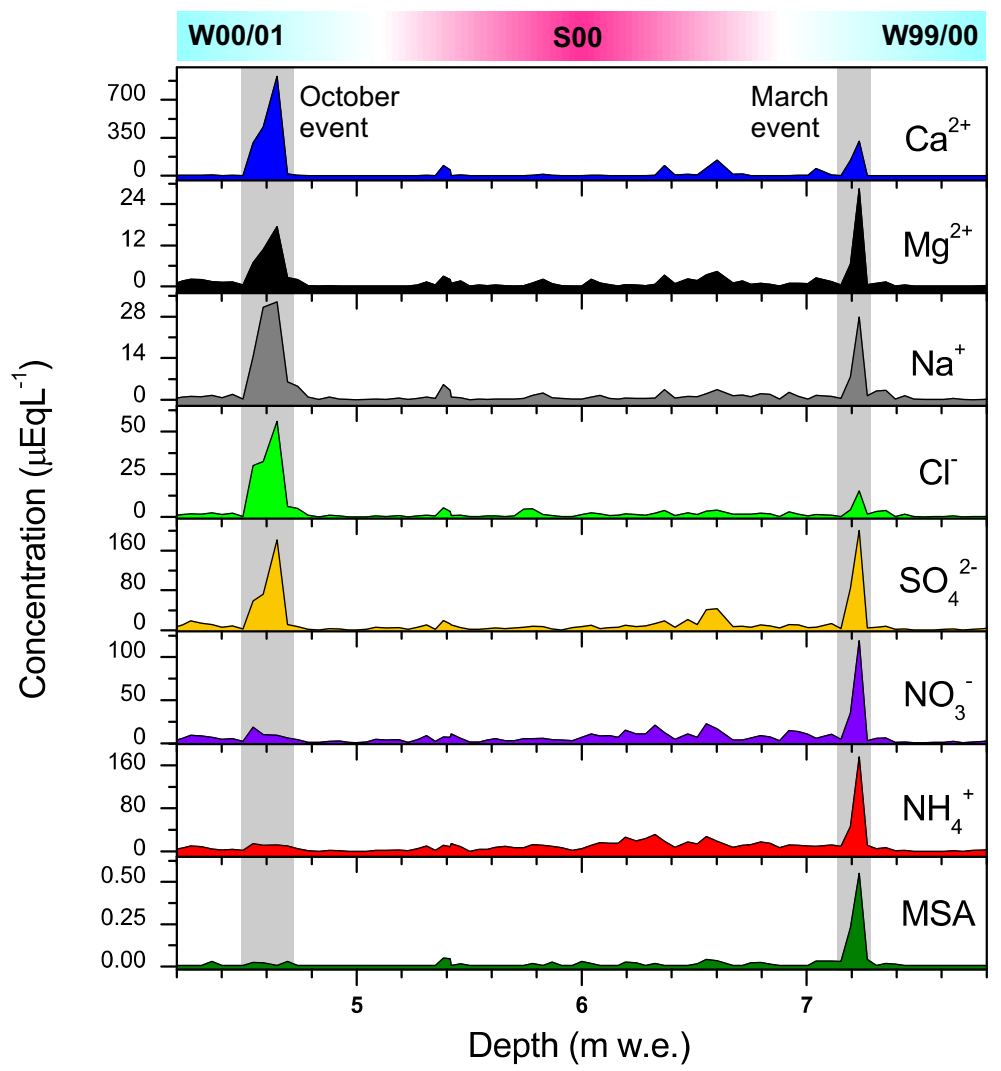

Fig. 2. Chemistry in the ice core from Piz Zupó for the year 2000. Shown as a function of ice core depth in $\mathrm{m}$ water equivalent (w.e.) are the concentrations of calcium $\left(\mathrm{Ca}^{2+}\right)$, magnesium $\left(\mathrm{Mg}^{2+}\right)$, sodium $\left(\mathrm{Na}^{+}\right)$, chloride $\left(\mathrm{Cl}^{-}\right)$, sulfate $\left(\mathrm{SO}_{4}^{2-}\right)$, nitrate $\left(\mathrm{NO}_{3}^{-}\right)$, ammonium $\left(\mathrm{NH}_{4}^{+}\right)$, and methanesulphonic acid (MSA) in micro equivalent per litre $\left(\mu \mathrm{EqL} \mathrm{L}^{-1}\right) \cdot \mathrm{H}^{+}$(not shown) reflects the acidity of the ice and behaves very similar to $\mathrm{NO}_{3}^{-}$, while potassium $\left(\mathrm{K}^{+}\right)$and oxalate $\left(\mathrm{C}_{2} \mathrm{O}_{4}^{-}\right)$(not shown) peak similarly to $\mathrm{Mg}^{2+}$. The areas shaded in gray denote the sections influenced by large amounts of mineral aerosol (dust events).

The dust event assigned to October 2000 was the only one in the entire core visible by its yellow colour. This event was previously detected in a shallow core drilled at the same site in May 2001. In that core the yellow layer was observed at a depth of $2.7 \mathrm{~m}$ w.e., resulting in an accumulation of $1.9 \mathrm{~m}$ w.e. during the 9-month period between the two drilling campaigns (May 2001-March 2002). This value is in very good agreement with the annual accumulation rate deduced from the entire core and thus strongly supports the dating.

The second (earlier) dust event in the ice core was at a depth of 7.1-7.3 $\mathrm{m}$ w.e. and had elevated levels for most chemical ions, especially $\mathrm{MSA}, \mathrm{Cl}^{-}, \mathrm{NO}_{3}^{-}, \mathrm{SO}_{4}^{2-}, \mathrm{C}_{2} \mathrm{O}_{4}^{2-}$, $\mathrm{Na}^{+}, \mathrm{NH}_{4}^{+}, \mathrm{K}^{+}, \mathrm{Mg}^{2+}, \mathrm{Ca}^{2+}$, and $\mathrm{H}^{+}$. This event shows remarkably high concentrations of $\mathrm{MSA}, \mathrm{NO}_{3}^{-}$, and $\mathrm{NH}_{4}^{+}$, the largest within the 11-yr period covered by the ice core. $\delta^{18} \mathrm{O}$ was relatively low during this event. Prior to this event the isotopic signature and the chemical species were low, as it is typical of winter conditions. Following the event, these indicators were characteristic of spring-summer with increased $\delta^{18} \mathrm{O}$ values and elevated concentrations of anthro- pogenic species. The total suspended particle (TSP) record from nearby Jungfraujoch (not shown) was also examined and two strong episodes with TSP values $>20 \mu \mathrm{g} \mathrm{m}^{-3}$ observed for the two-day filters 17/18 and 23/24 March, indicating that either or both of these periods may be preserved in the Piz Zupó record.

\section{Identification of the dust transport history}

In order to create a link between the specific meteorological situation leading to dust transport at Piz Zupó and the chemical signal in the ice core, we developed a refined backtrajectory method for the analysis of dust transport. It uses specific meteorological criteria to identify mobilisation and wet deposition periods of dust.

\subsection{Back-trajectory calculations}

Based on the approximate dating of the dust events described above, the potential for dust transport to Piz Zupó was studied in detail for the whole of March and October 2000. For 


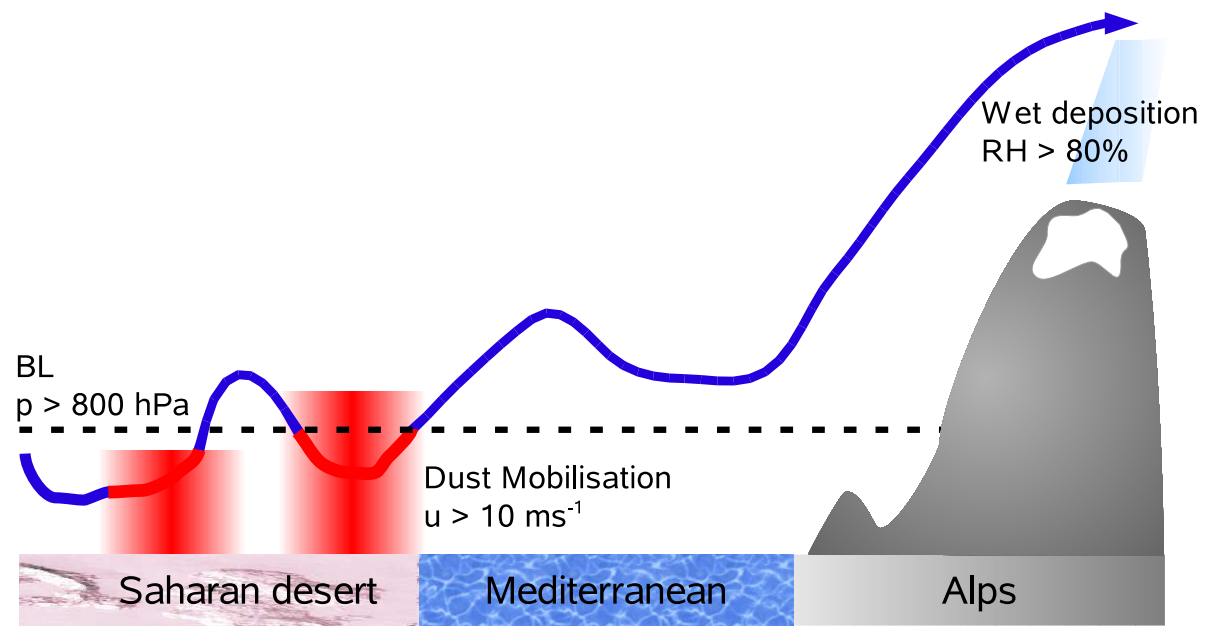

Fig. 3. Schematic of the methodology and selection criteria used for the identification of potential dust source regions from back-trajectory analysis. See text for details.

both months, three-dimensional kinematic trajectories originating from Piz Zupó at an 6-h interval were calculated 10 days backward in time by means of the trajectory tool LAGRANTO (Wernli and Davies, 1997). Together with the location of the air parcels, additional atmospheric variables, namely relative humidity, specific humidity, and wind velocity were traced and stored every $6 \mathrm{~h}$.

In order to account for the inherent uncertainty of trajectory calculations, the back-trajectories were calculated as ensembles arriving within a specific arrival domain. Horizontally, arrival points of trajectories were set up as a 5-point cross with one central arrival point at the location of Piz Zupó glacier, surrounded by four arrival points with an offset of $0.5^{\circ}$ in the $\mathrm{E}, \mathrm{W}, \mathrm{S}$, and $\mathrm{N}$ direction, respectively. Vertically, arrival levels ranging from 800 to $410 \mathrm{hPa}$ (about 2 to $7 \mathrm{~km}$ a.s.1.) at intervals of $30 \mathrm{hPa}$ were chosen. In total, ensembles with back-trajectories from 70 starting points were calculated daily at 00Z, 06Z, 12Z, and $18 \mathrm{Z}$.

From the back-trajectories, possible areas of dust mobilisation were extracted by means of objective selection criteria. Due to the setup of the trajectory calculations, only air parcels were considered which ultimately arrive at Piz Zupó. First, air parcels were selected exhibiting conditions suitable for dust deposition at the arrival site (Sect. 4.2), then they were traced backwards to identify the areas of potential dust mobilisation (Sect. 4.3). The dust mobilisation locations identified from this methodology were considered as "potential" dust source regions, and verified with observational data wherever possible.

\subsection{Dust deposition}

Mineral aerosols can either be removed from air parcels by wet deposition (precipitation scavenging) or by dry deposition mechanisms. Further from the mobilisation area, wet deposition is considered to be far more effective than dry deposition (Schwikowski et al., 1995), which quickly decreases as dust is transported away from its mobilisation area (Duce et al., 1991). In fact, Osada et al. (2004) showed for a site in Japan that significant layers of mineral aerosol in snow can only form by wet deposition, typically when dusty air masses merge with precipitation-bearing frontal systems. Hence, we assume that wet deposition is most important for forming dust layers in snow at our Alpine site as well.

Consequently, in our back-trajectory analysis, we only considered those trajectories relevant for formation of a dust layer in the ice core which experienced wet deposition at the arrival site. Precipitation (and wet deposition) was assumed to occur when the relative humidity $(R H)$ of an air parcel exceeded $80 \%$ (Fig. 3). This threshold value follows the cloud and precipitation parameterisation scheme incorporated in the ECMWF model ${ }^{2}$. In addition, all air parcels of a trajectory ensemble that arrive below the uppermost "precipitating" air parcel were considered as experiencing belowcloud scavenging of mineral aerosol.

Wet removal of dust prior to arrival was estimated by counting the number of occasions in a dust-laden air parcel where $R H$ exceeded $80 \%$ during the time period from dust mobilisation until $24 \mathrm{~h}$ before arrival at Piz Zupó. Independent confirmation of potential scavenging of the dust plumes along the flight path and at the arrival site was obtained from visually examining the cloud structure in Meteosat visible and IR imagery. Gravitational settling of particles along the transport path was not considered quantitatively in this study. However, in the interpretation of our results we take into account that due to this process the potential dust load is likely to decrease with increasing travel time.

\footnotetext{
${ }^{2}$ ECMWF, 2004: IFS Documentation Cycle CY28r1, Sect. IV.6, http://www.ecmwf.int/research/ifsdocs/CY28r1/index.html
} 
(a)

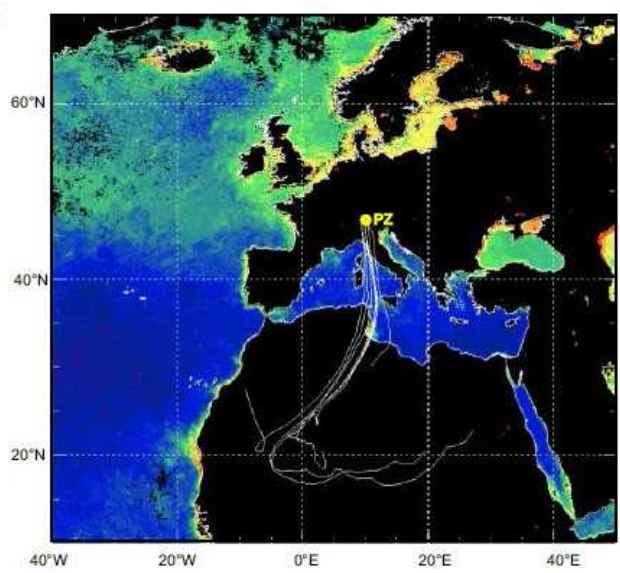

(b)

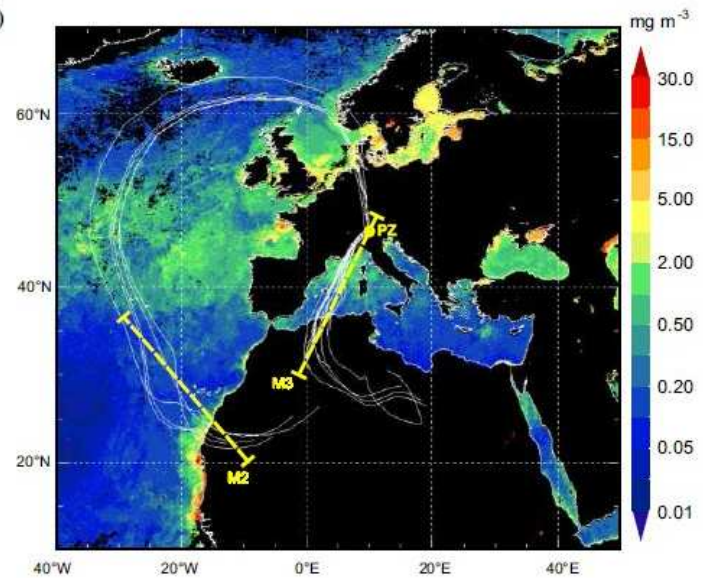

Fig. 4. Composite maps of weekly chlorophyll $a$ concentration and representative examples of 10-day back-trajectories arriving at Piz Zupó (PZ) in (a) on 18Z 14 October and (b) 12Z 18 March (M2) and 06Z 24 March 2000 (M3). Cross-sections indicated in (b) by dashed, yellow lines are shown in Fig. 14. The chlorophyll $a$ maps and cross-sections are interpreted and discussed in Sect. 6.2.

\subsection{Dust mobilisation}

Again, objective criteria were adopted to extract locations along the backward trajectories where dust mobilisation potentially occurred (Fig. 3). These are (i) the presence of dry, suspendible soil material, (ii) sparse vegetation cover, (iii) sufficiently high wind velocities near the ground, and (iv) strong updrafts which are able to lift the suspended material to a sufficient altitude for long-range transport (Shao and Leslie, 1997). These criteria are also typically considered as relevant in large-scale dust transport models (Tegen and Fung, 1994; Mahowald and Dufresne, 2004).

According to our interpretation, criteria (i) and (ii) are fulfilled when an air parcel is located over an area in Africa north of $10^{\circ} \mathrm{N}$ where the vegetation map from DeFries and Townshend (1994) shows one of the categories "bare", "shrubs and bare soil", or "cultivated". Criterion (iii) is met when the air parcel is sufficiently close to the ground to pick up mineral aerosol, i.e. within the assumedly well-mixed BL. The top of the BL was defined here as the $800 \mathrm{hPa}$ isosurface $(\sim 1.9 \mathrm{~km}$ a.s.l.). Additionally, the wind speed at the location of the air parcel within the BL has to be greater or equal to a mobilisation threshold of $10 \mathrm{~m} \mathrm{~s}^{-1}$. Sufficiently strong updrafts (criterion iv) are accounted for implicitly by the fact that the air parcel trajectories ultimately all arrive at Piz Zupó. Accordingly, our algorithm identifies potential dust uptake locations along a trajectory if all these criteria are fulfilled. The criteria were checked every $6 \mathrm{~h}$ along the individual 10-day trajectories. Thereby, a single trajectory can be associated with and hence carry dust from several potential dust uptake locations.

Sensitivity analysis showed that the dust uptake regions depend only quantitatively on the thresholds for mobilisation wind speed and boundary layer height, while the overall patterns remain the same. Currently, the aim of the proposed methodology is to provide a qualitative view of dust mobilisation and transport. Further dust-related processes would have to be included to provide quantitative answers from these Lagrangian modelling efforts (Sect. 7).

\section{Meteorological development during dust transport events}

Indeed, using this Lagrangian approach, dust transport events from the Sahara to the Piz Zupó glacier site could be identified during the two time periods March and October 2000, as suggested by the ice core analysis (Sect. 3).

Detailed meteorological analyses are presented for both events which describe the specific synoptic situation associated with dust transport to central Europe. In combination with our extended back-trajectory analysis, we can reveal what types of meteorologic development were associated with dust transports to the Alps. The general transport patterns during the two dust events are illustrated by a representative selection of back-trajectories that fulfil the criteria for dust mobilisation and deposition (Fig. 4).

Time series of variables characterising the temporal evolution of a particular Saharan dust event were derived from the enhanced back-trajectory method (Figs. 5 and 9). This type of visualisation combines in one figure four kinds of information: (1) the estimates of dust mobilisation in the Sahara for a particular dust event, given as the number of air parcel positions where the mobilisation criteria were fulfilled, (2) the strength of dust transport to Piz Zupó given by the number of air parcels arriving which previously experienced dust mobilisation, (3) the extent of wet deposition in dust-laden air parcels prior to arrival in the Alpine area, and (4) the precipitation at the arrival site, calculated from the decrease in 
(a) Precipitation

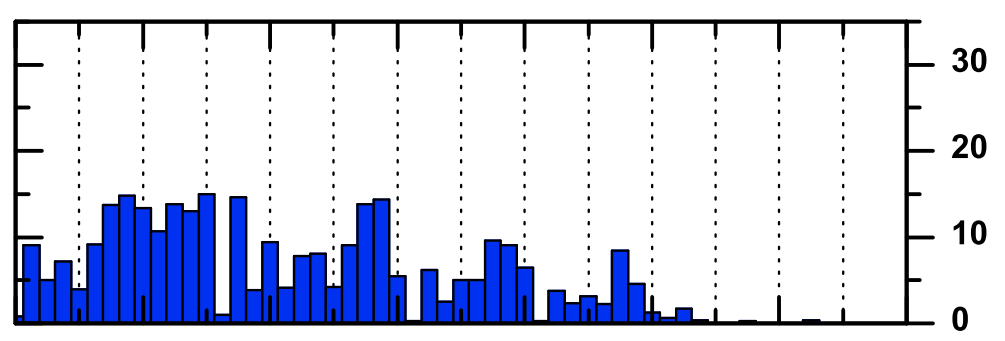

(b) Pre-arrival wet deposition

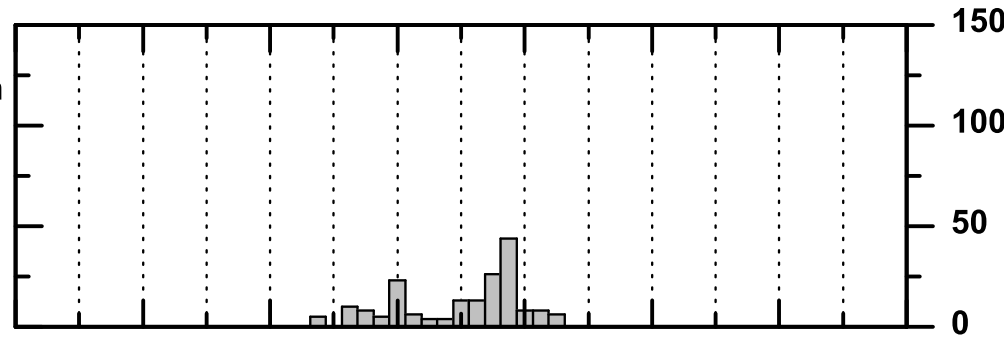

(c) Dust arrival

(d) Dust mobilisation

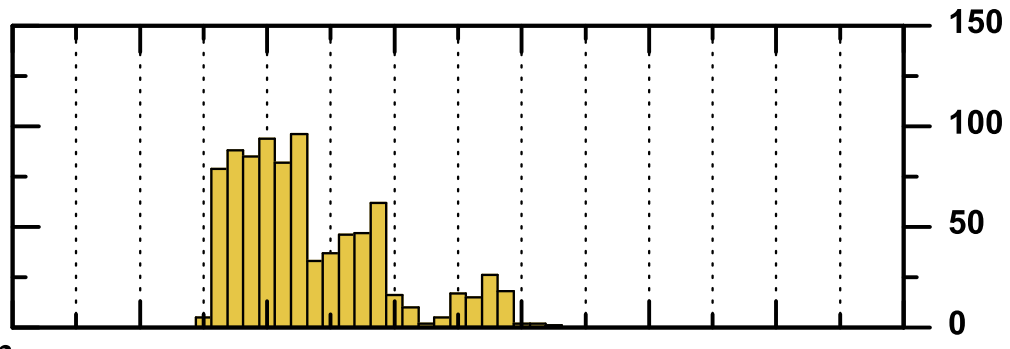

150

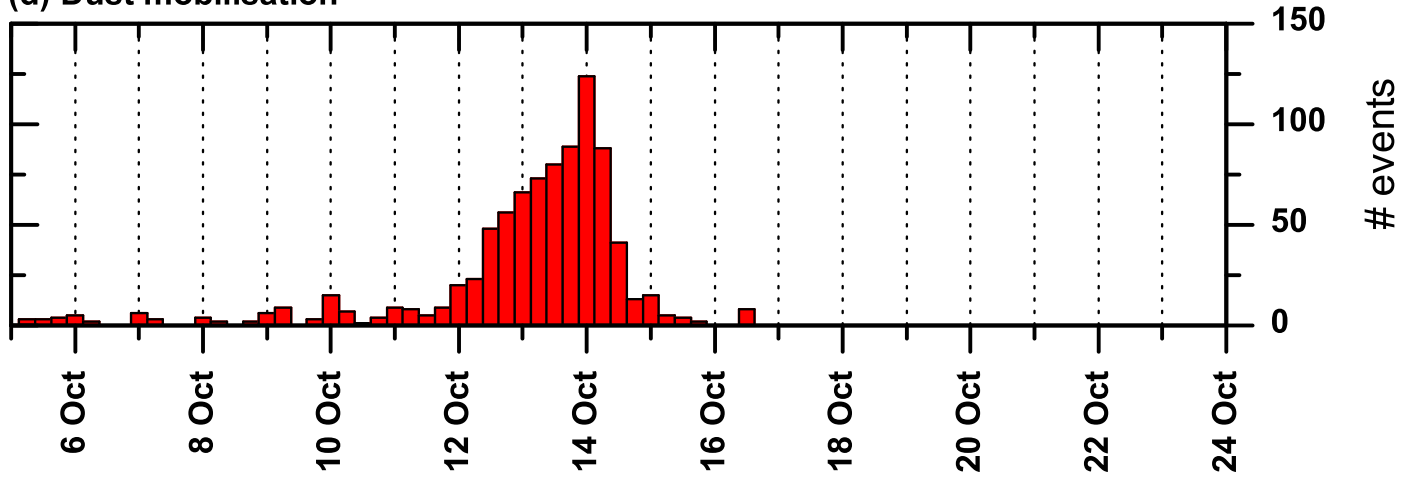

Fig. 5. Temporal evolution of dust transport characteristics extracted from the extended back-trajectory analysis for the October event. (a) precipitation estimate, (b) wet deposition until $24 \mathrm{~h}$ before arrival, (c) arriving dust-laden air parcels, (d) dust mobilisations.

specific humidity in an air parcel during the last $6 \mathrm{~h}$ before arrival at Piz Zupó (Wernli, 1997).

Three types of visualisations are used to characterise the synoptic-scale conditions during the dust events. First, isentropic PV charts with horizontal flow vectors (only where the velocity is $>10 \mathrm{~m} \mathrm{~s}^{-1}$ ) depict the dynamical processes in the tropopause region (see for instance Fig. 6a). The tropopause is defined as the 2-pvu surface and it separates tropospheric (blue and beige colours, low PV) from stratospheric air masses (red, yellow and green colours, high PV). Second, the state of the atmosphere in the lower troposphere is investigated with the SLP and $850 \mathrm{hPa}$ equivalent potential temperature $\left(\theta_{e}\right)$ fields (e.g. Fig. 6c). Third, Meteosat IR satellite images are shown for the European sector (e.g. Fig. 6b). The exact domain for the satellite images is indicated by the white dashed frame in Figs. 6a, c. In addition, the actual position of all trajectories that fulfilled the criteria mentioned above for potential dust transport to Piz Zupó are superimposed on the meteorological maps at the respective time instant. This permits to follow a potential dust cloud along its path from the area of mobilisation towards the deposition site concomitantly with the large-scale meteorological development. Different colours have been used to demark the trajectory position during dust mobilisation (red in 
(a) $12 \mathrm{Z} 11$ October 2000

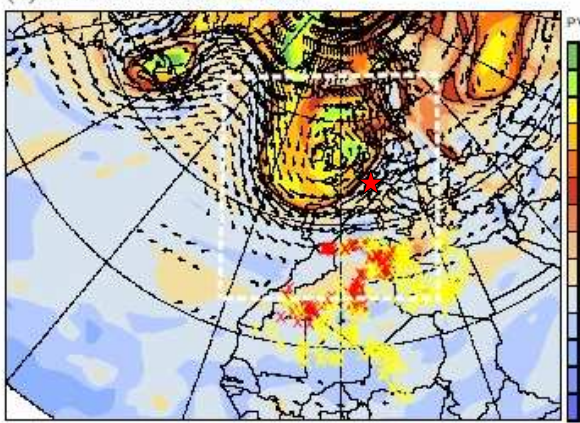

(d) $12 Z 13$ October 2000

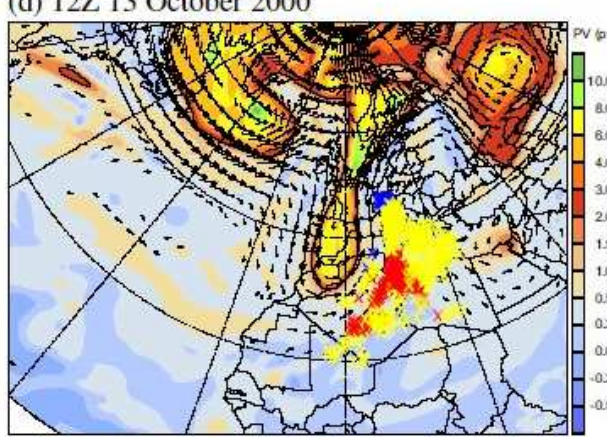

(g) $12 Z 15$ October 2000

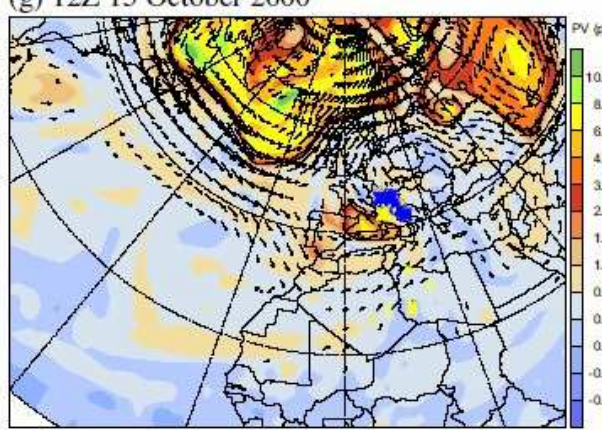

(b)

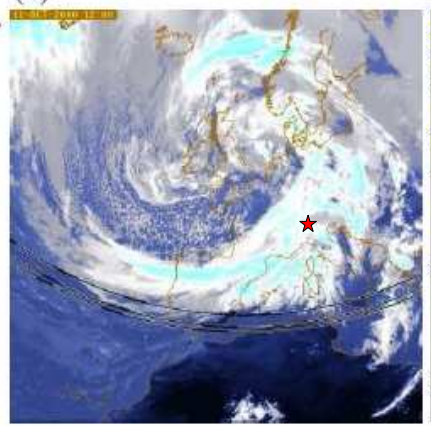

(e)

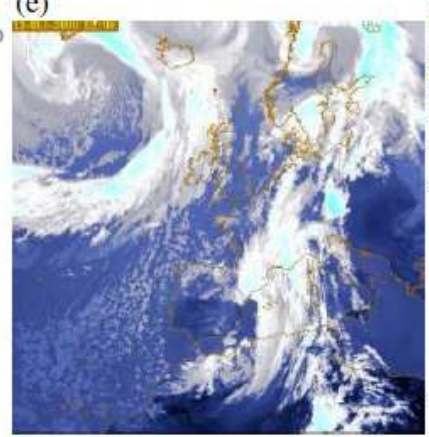

(h)

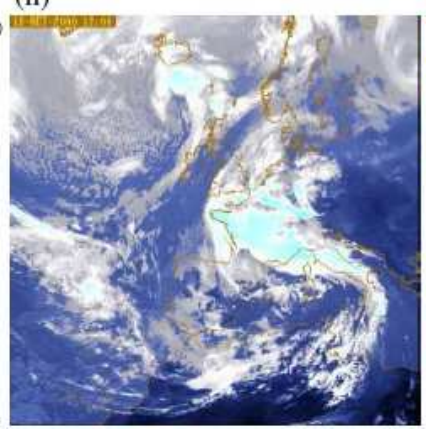

(c)

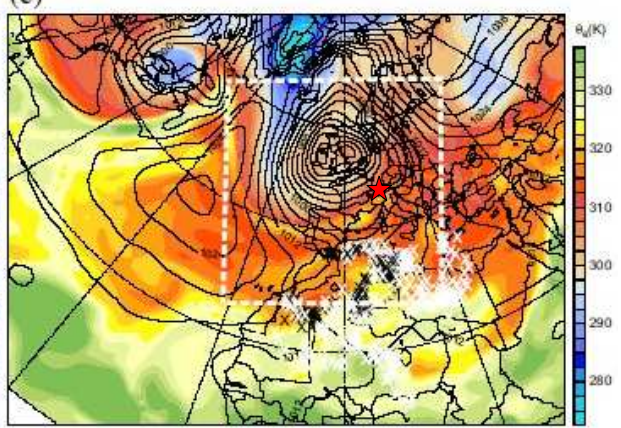

(f)

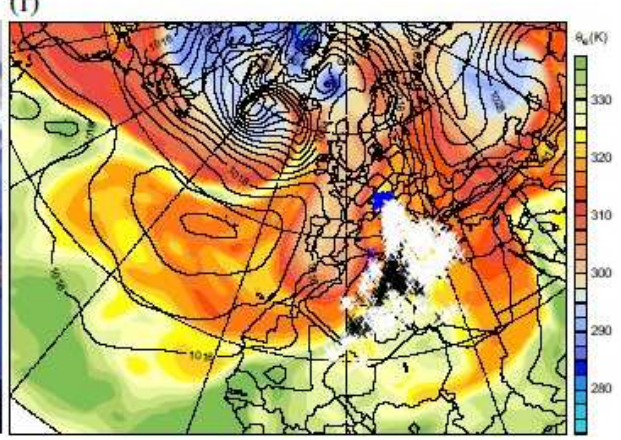

(i)

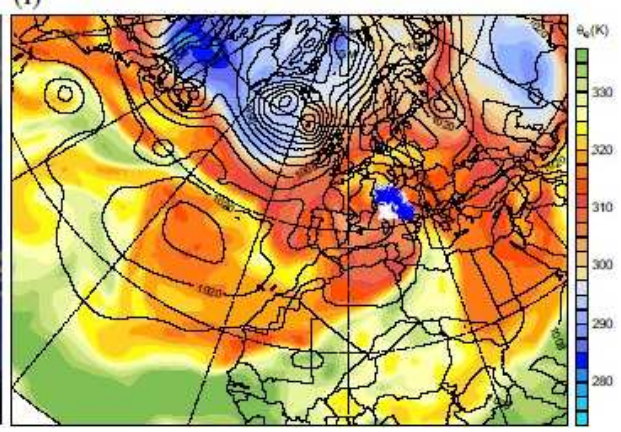

Fig. 6. Meteorological situation during the October 2000 dust event (11 to 15 October 2000). Left to right column: Potential vorticity (PV) and wind vectors at $320 \mathrm{~K}$, Meteosat IR satellite image, $\theta_{e}$ and sea level pressure (SLP) at $850 \mathrm{hPa}$. Red star in (a-c) shows the approximate location of Piz Zupó.For details see text. See electronic supplement (http://www.atmos-chem-phys.net/6/667/acp-6-667-sp.zip) to this paper for a movie of this figure.

the upper-level, black in the low-level charts), dust transport (yellow in the upper-level, white in the low-level charts) and wet deposition (blue). Note that dust mobilisation is only indicated for trajectories that eventually reach Piz Zupó, therefore the red/black crosses do not give an overall picture of dust mobilisation.

Electronic supplements to this paper are available, which provide insightful animations of Figs. 6 and 10 for the full periods of the March and October dust events (see http:// www.atmos-chem-phys.net/6/667/acp-6-667-sp.zip or http: //www.iac.ethz.ch/staff/harald/sahara/).
5.1 Meteorological development during the October dust event

During the October event (Fig. 4a), a single dominant transport pathway leads from the Sahara across the Ligurian Sea (Fig. 1) directly to the Alps, where it was potentially deposited at Piz Zupó between 00Z 13 October-18Z 15 October (Table 1, O1).

Before 11 October, potential dust mobilisation was identified sporadically and dispersed across the Sahara region (Fig. 5d). A major dust mobilisation phase occurred during 18Z 11-18Z 15 October, in a region stretching from northern Mauritania across Algeria into Tunesia (Fig. 13a). In the eastern North Atlantic an intense low pressure system 


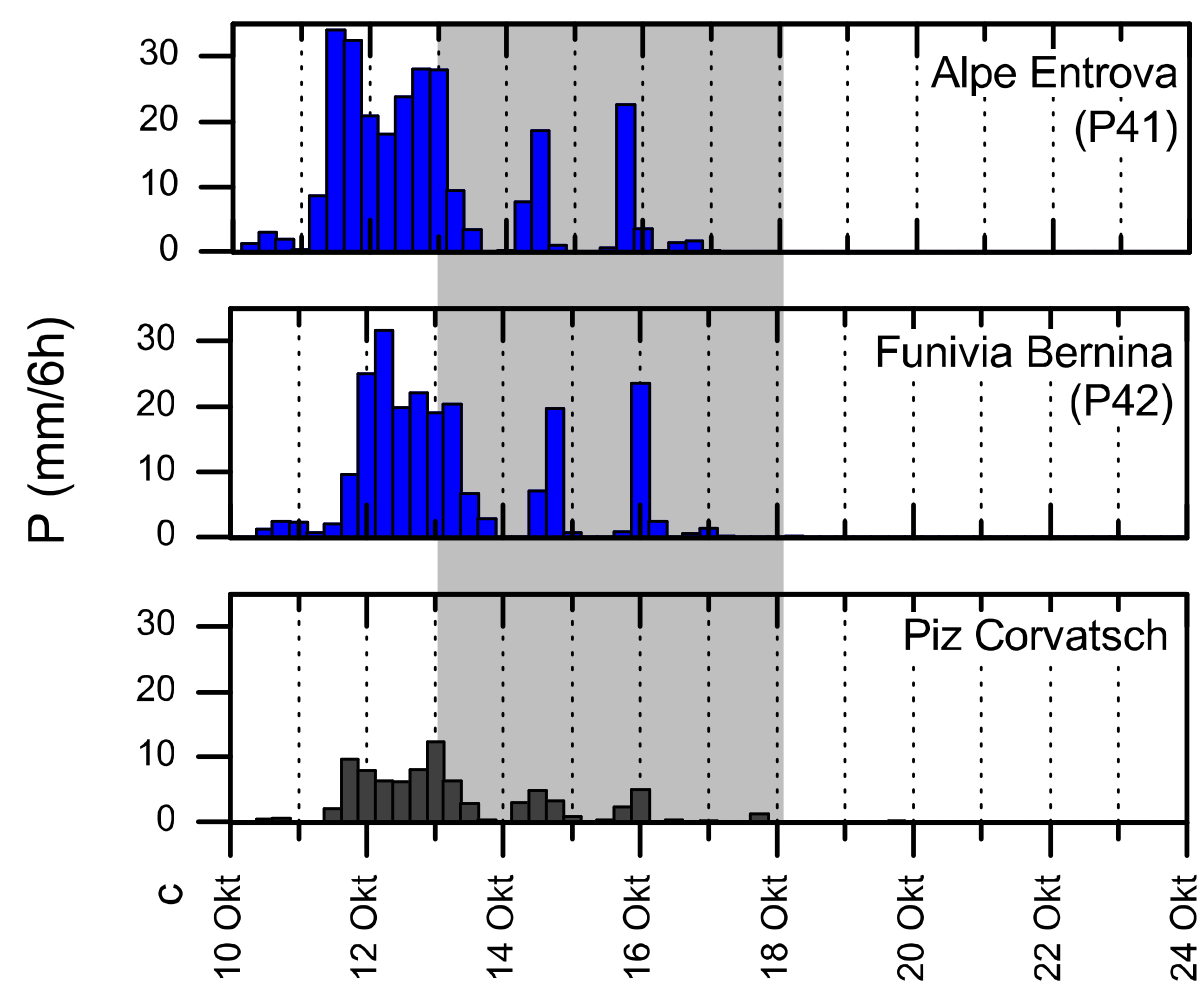

Fig. 7. Six-hourly accumulated precipitation at three meteorological stations south (P41, P42) and north (Piz Corvatsch) of Piz Zupó for 10-18 October 2000. The gray shaded area indicates the dust arrival period identified from the back-trajectory analysis (Fig. 5c).

Table 1. Potential timing and source regions of the Saharan dust mobilisation and deposition phases for the March and October 2000 dust events as identified from the extended back-trajectory analysis and visual inspection of IR satellite imagery.

\begin{tabular}{llll}
\hline Phase & Mobilisation & Deposition & Source regions \\
\hline M1 & 00Z 06-18Z 7 March 2000 & 06Z 14-18Z 15 March 2000 & Mauritania/Algeria \\
M2 & 18Z 08-06Z 12 March 2000 & 06Z 16-12Z 19 March 2000 & Algeria/Mauritania/Mali \\
M3 & 18Z 19-00Z 23 March 2000 & 12Z 23-12Z 26 March 2000 & Algeria/Libya \\
O1 & 18Z 11-18Z 15 Oct 2000 & 00Z 13-18Z 15 Oct 2000 & Algeria/Libya \\
\hline
\end{tabular}

developed and moved over the British Isles at $12 \mathrm{Z} 11$ October (Fig. 6c). The satellite image (Fig. 6b) reveals a prominent cold frontal cloud band that extends from Poland over the Alps and Spain to the Azores. At upper levels the cyclone was accompanied by a high-PV air mass on the $320 \mathrm{~K}$ isentrope that, at that time, induces a strong southwesterly flow to the Alps (Fig. 6a). Further south, strengthening low-level winds across the western Sahara led to dust mobilisation with some dust already entering the Mediterranean. During the next two days, a southwest-to-northeast oriented mid-level jet (with peak velocities of more than $30 \mathrm{~m} \mathrm{~s}^{-1}$ between 500 and $800 \mathrm{hPa}$, not shown) developed and led to an intensification of dust mobilisation over Algeria during 12-13 October (Fig. 5d).
Until 12Z 13 October the upper-level PV anomaly elongated meridionally and developed into a so-called PV streamer that extended to Northern Africa (Fig. 6d). Along its eastern side, the streamer veered the flow from Algeria directly towards the Alps. Near the surface, a tongue with low $\theta_{e}$ was advected from the North towards Spain and Morocco, and a tongue with high $\theta_{e}$ from Africa over the Alps to the Baltic Sea. A sharp cold front, running parallel to the upper-level streamer demarked the separation between these strongly differing air masses (Fig. 6f). It was associated with a relatively broad cloud band extending from Algeria over the Alps to northern Germany (Fig. 6e). At that time, there had been heavy precipitation for more than $24 \mathrm{~h}$ along the Alpine southside (Fig. 7). This heavy precipitation 
period is also apparent in the precipitation extracted from our back-trajectory analysis (Fig. 5a). Ahead of the upper-level streamer, a large dust plume had entered the central Mediterranean and some wet deposition already occurred in the Alps. The SeaWiFS visible image from 13 October (Fig. 8) indicates the presence of adjacent streaks of dry dusty and moist cloudy air masses that may have started mixing on their way to the Alps. The trajectory analysis indicates that at Piz Zupó the dust event sets in rather abruptly after 00Z 13 October (Fig. 5c). At that time, dust mobilisation continued near Tunesia. The very short time span between dust mobilisation and deposition of about $24-48 \mathrm{~h}$ reflects the rapid northward transport during this particular meteorological situation.

During the next two days, until $12 \mathrm{Z} 15$ October, the PV streamer broke up and evolved into a PV cut-off located over the western Mediterranean (Fig. 6g). It did not reach into northern Africa and the export of Saharan dust into the Mediterranean ceased (Fig. 5d). However, previously mobilised dust was transported on its eastern flank from S-SE directions towards the Alps where widespread wet deposition occurred (Fig. 5b). The surface front deformed strongly (Fig. 6i) and a large-scale cloud system with embedded convection covered all of Italy and France (Fig. 6h). It appears to be responsible for the more intermittent rainfall observed near Piz Zupó between 13 and 17 October (Fig. 7), possibly reflecting the arrival of mixed dusty and moist air masses. A more intermittent precipitation regime is also apparent in the trajectory-based precipitation series (Fig. 5a). By $18 \mathrm{Z} 15$ October, the last of the identified dust parcels had arrived at Piz Zupó (Fig. 5c). During the same period, wet deposition prior to arrival became increasingly wide-spread (Fig. 5b), and thereafter little precipitation was observed at the three stations until the end of the month.

\subsection{Meteorological development during the March dust event}

For the more complex March event trajectory analysis indicates a first minor dust phase (M1) (not shown) followed by two important episodes (M2, M3) characterised by different transport pathways (see Table 1 and Fig. 4b). During M2, dust was ejected across the African west coast, transported in a rather exceptional pathway over the eastern North Atlantic, and reached about $60^{\circ} \mathrm{N}$ before approaching the arrival site from northerly directions. In contrast, transport during M3 was again mainly northward, similar to the October event.

The first minor dust mobilisation phase in March 2000 (M1, cf. Table 1) took place in response to a cyclonic system located over the Canary Islands. It first mobilised dust in the border region between Algeria, Mali and Mauritania and led to the ejection of a dust plume into the Atlantic during $12 \mathrm{Z}$ 05-18Z 7 March (Fig. 9d). The cyclone is still visible on the satellite image from 12Z 11 March over southern Portugal (Fig. 10b) associated with a small-scale upper-level PV cutoff (Fig. 10a) and a weak signal in the SLP field (Fig. 10c).

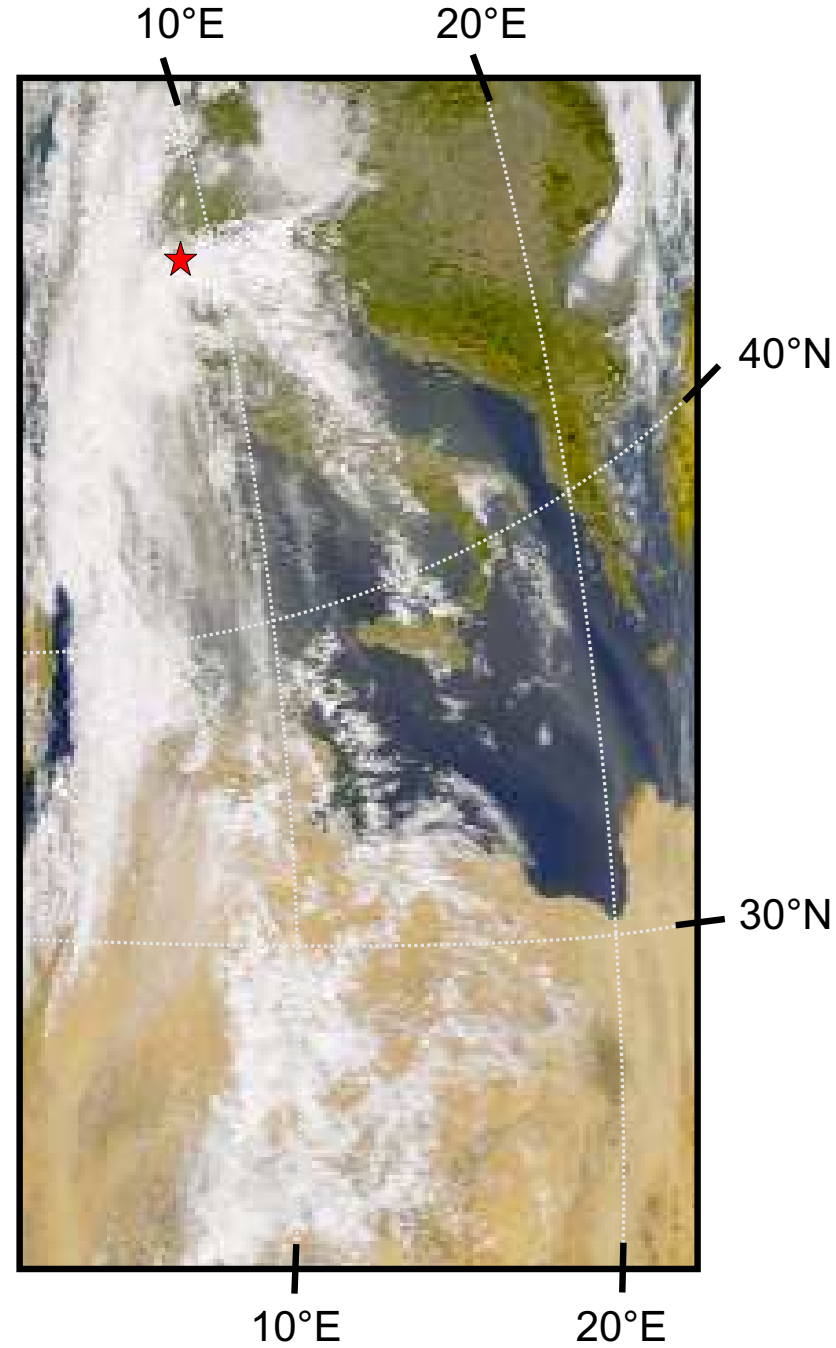

Fig. 8. SeaWiFS visible wavelength satellite image of a dust plume over the central Mediterranean on 13 October 2000. Red star shows the approximate location of Piz Zupó.

The ejected dust parcels were picked up by the westerlies to the west of Ireland after 11 March and were advected across France towards the Alps. This principal transport pattern was already described by Prodi and Fea (1978), and Goudie and Middleton (2001) list numerous Saharan dust falls over the British Isles during the twentieth century, including an event in Oxfordshire on 13 March 2000 which was probably related to the M1 dust plume. In a Lagrangian dust transport study, Ryall et al. (2002) also modelled Saharan dust transport to Great Britain on, among other days, 13-14 March 2000. However, widespread rain occurred among the dustladen air parcels during the last $72 \mathrm{~h}$ before arriving at the Alps. This is reflected by the pre-arrival wet deposition detected for the M1 event (Fig. 9b). It is therefore unlikely that a significant amount of dust from phase M1 was deposited at Piz Zupó during 06Z 14-18Z 15 March. 
(a) Precipitation

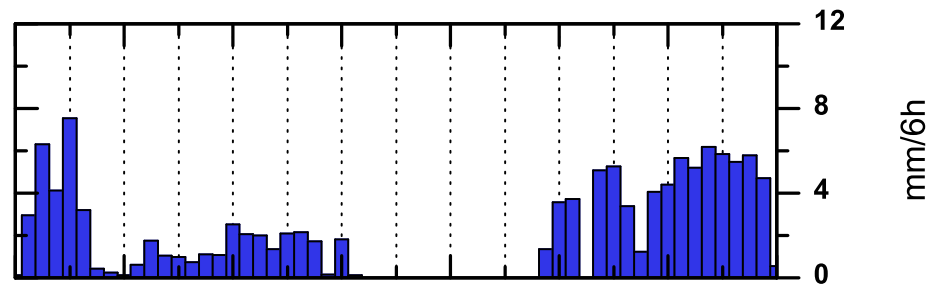

(b)

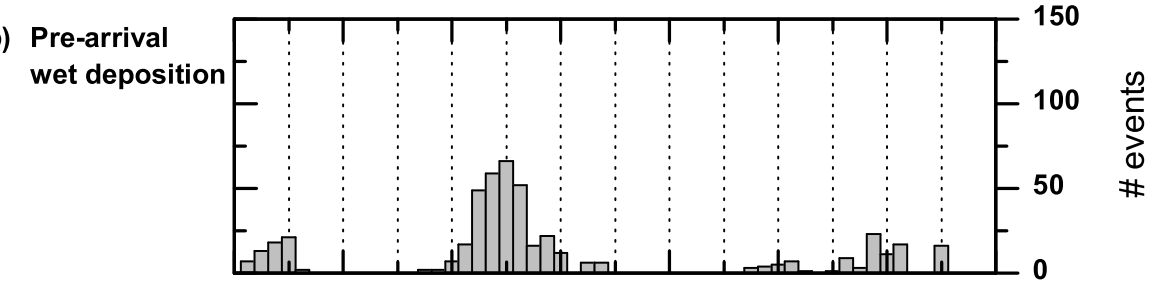

(c) Dust arrival

(d) Dust mobilisation
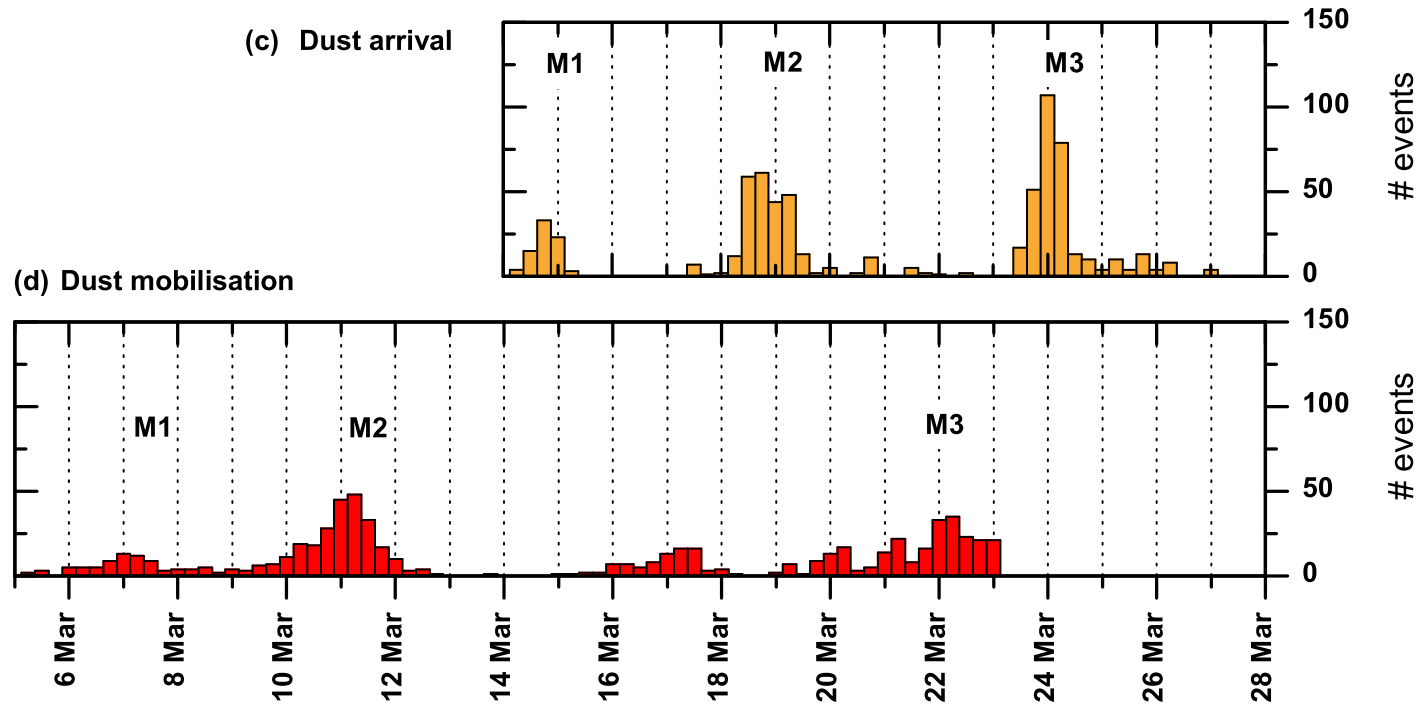

Fig. 9. Temporal evolution of dust transport characteristics extracted from the extended back-trajectory analysis for the March event. (a) precipitation estimate, (b) wet deposition until $24 \mathrm{~h}$ before arrival, (c) arriving dust-laden air parcels, (d) dust mobilisation.

A second major dust mobilisation phase (M2) was identified from the trajectory analysis during $18 \mathrm{Z}$ 08-06Z 12 March (Fig. 9d), first in south-western Algeria and Mali, later also in Mauritania (Figs. 10a, 13b). During 12Z 10-06Z 12 March a large dust plume left Africa near the Capverde Islands $\left(20^{\circ} \mathrm{N}, 20^{\circ} \mathrm{W}\right)$. This is confirmed by the SeaWiFS satellite imagery (Fig. 11a) and by the 3rd-level product from SeaWiFS, the Aerosol Optical Thickness one-week composite (not shown). On 14 March the dust plume was picked up by a weak cyclone in the eastern North Atlantic (near $40^{\circ} \mathrm{N}, 40^{\circ} \mathrm{E}$, see Figs. 10d, f). The decaying cyclone was associated with a minimum in SLP, a uniform low-level temperature field and a small upper-level PV cut-off. This feature was essential to advect the Saharan dust northward into a pronounced upper-level ridge and jet-stream system. Almost no clouds and rain formed in the vicinity of the dust plume until it passed Iceland to the north of a pronounced surface high-pressure system on 12Z 16 March (Figs. 10g, i). At that time a strong northerly flow was established towards the Alps, as can be seen in the IR satellite image by the sharp transition between orographic clouds and cloudfree conditions south of the Alps and Pyrenees due to Föhn (Fig. 10h). During the following two days, this northerly flow advected the dust cloud rapidly towards Central Europe. Partial rain-out occurred over Germany (see Fig. 9b and electronic supplement). About 9 days after mobilisation, the remainder of dust plume M2 arrived at Piz Zupó during 12Z 17-06Z 19 March (Fig. 9c), considerably later than for the October event. Precipitation data close to Piz Zupó indicate that wet deposition of the remaining dust may have occurred during 17-18 March, although precipitation intensities were small and limited to high elevations and the slopes facing north (Fig. 12). The trajectory-based precipitation estimate also shows small precipitation intensities during this period (Fig. 9a). 
(a) 12Z 11 March 2000

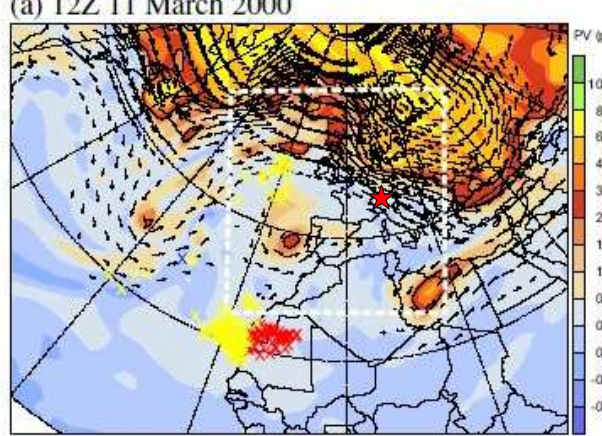

(d) 00Z 14 March 2000

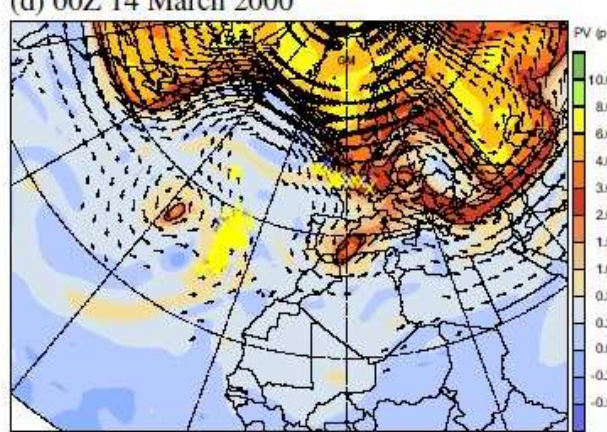

(g) 12Z 16 March 2000

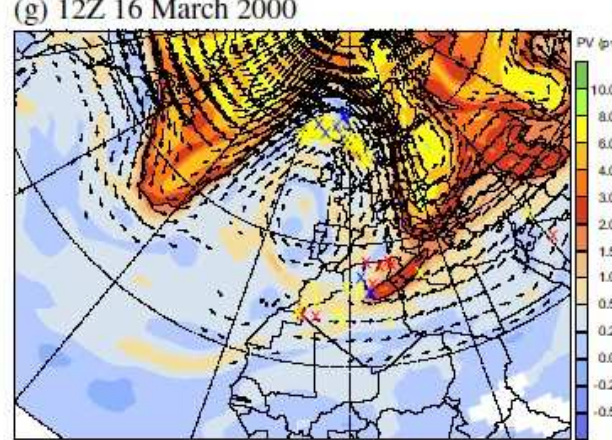

(j) 00Z 22 March 2000

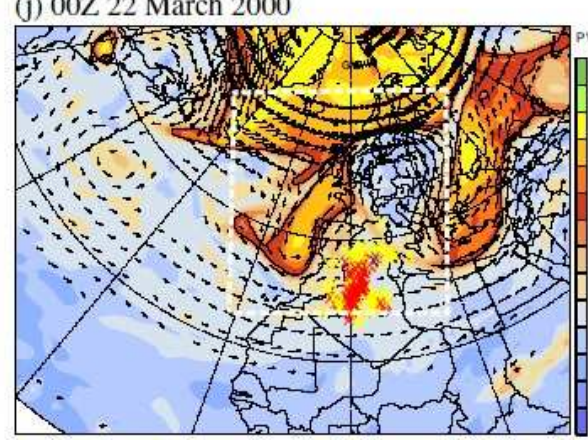

(b)

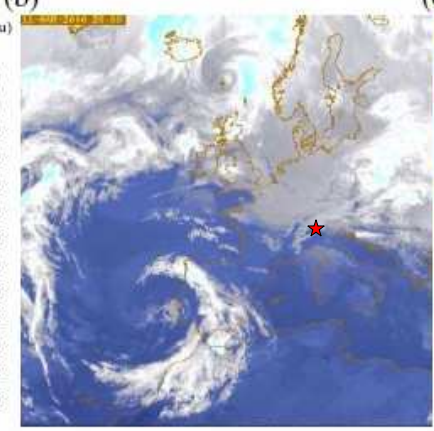

(e)

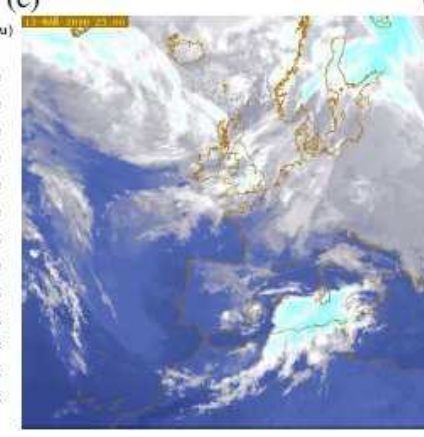

(h)

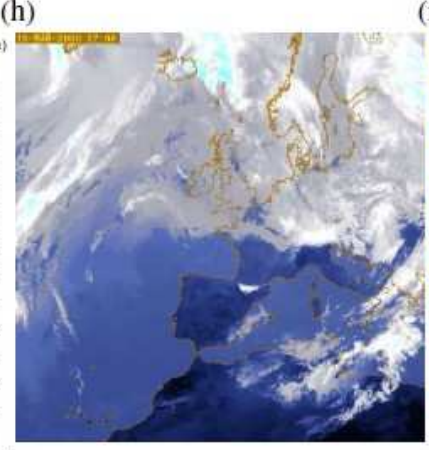

(k)

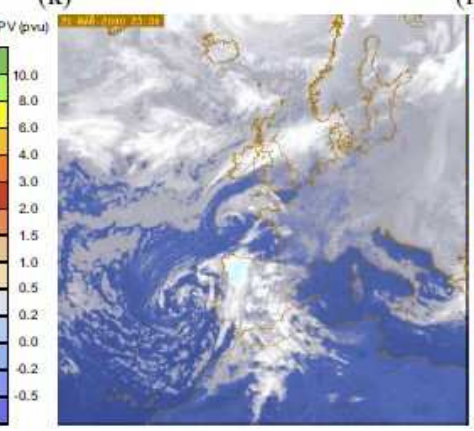

(c)

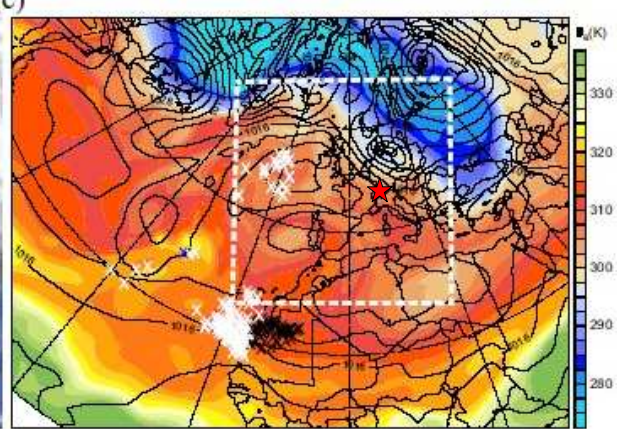

(f)

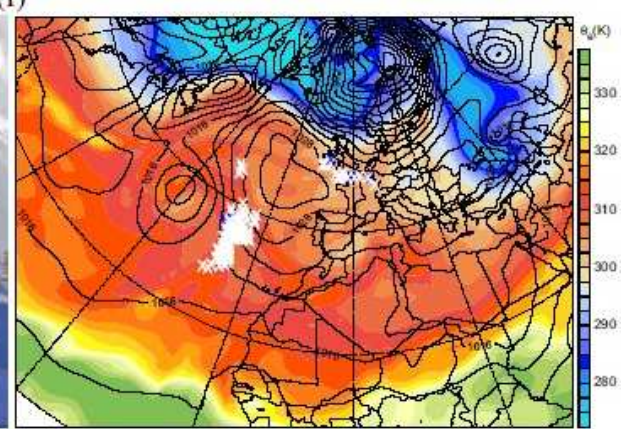

(i)

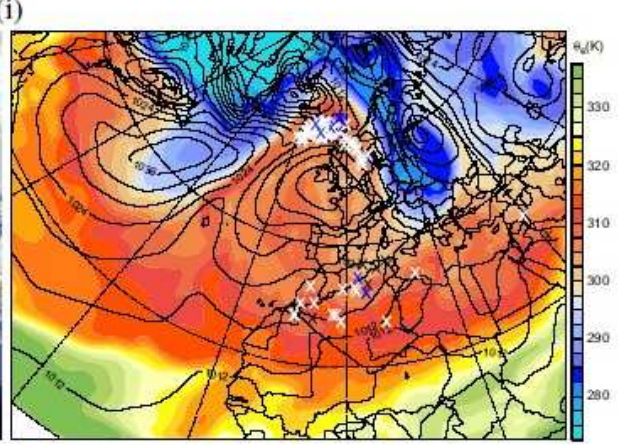

(1)

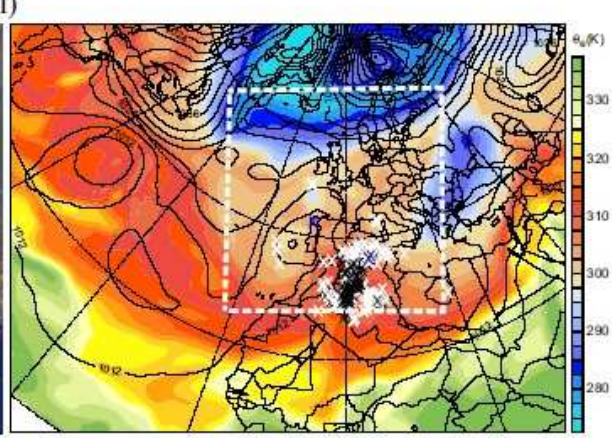

Fig. 10. Meteorological situation during 11 to 16 March 2000 (Phase M2) and 22 March 2000 (Phase M3). Left to right: PV and wind vectors at $315 \mathrm{~K}$, infrared satellite image, $\theta_{e}$ and sea level pressure (SLP) at $850 \mathrm{hPa}$. Red star in (a-c) shows the approximate location of Piz Zupó. For details see text. See electronic supplement (http://www.atmos-chem-phys.net/6/667/acp-6-667-sp.zip) to this paper for a movie of this figure. 


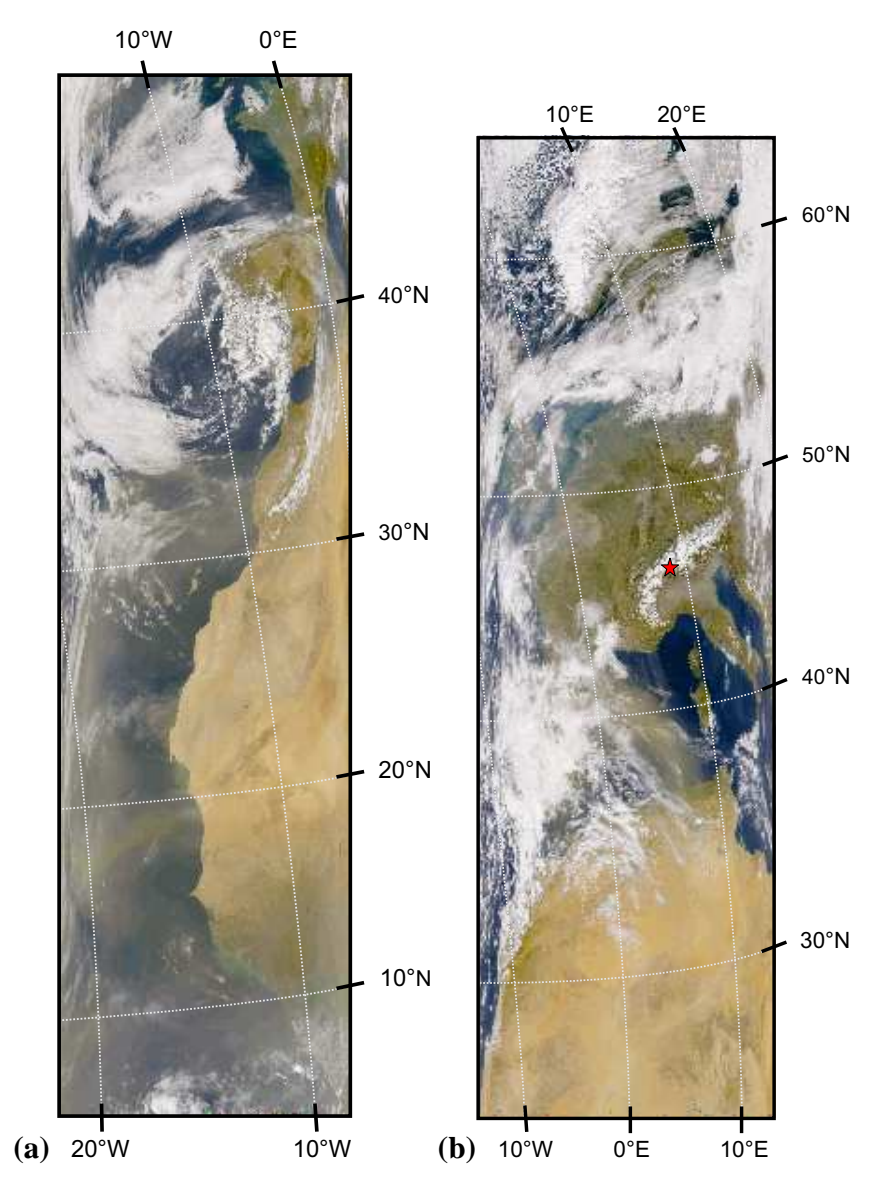

Fig. 11. SeaWiFS visible wavelength satellite images of (a) the dust plume of phase M2 on 12 March 2000 to the west of Africa, (b) the dust plume of phase M3 on 22 March 2000 in the Mediterranean. Red star shows the approximate location of Piz Zupó.

A third pronounced dust mobilisation phase (M3) between 18Z 19-00Z 23 March (Fig. 9d) was confined to a narrow band located across the Algerian desert (Figs. 10j, 13b). Similarly to the October event, the dust mobilisation appears to be closely related to a PV streamer reaching into northern Africa, which induced strong southerly winds on its eastern flank. As an interesting side remark it is noted that this PV streamer developed in a very different way compared to the streamer in the October event. The latter evolved due to narrowing of an upper-level trough. In contrast, in March a previous large streamer extending from the Black Sea over the entire Mediterranean broke up on 21 March near the Atlas mountains. The cut-off PV vortex rotated and moved slightly northward until it rejoined the stratospheric reservoir near Scotland at 00Z 22 March (Fig. 10j). This "secondary streamer" led to the ejection of the dust plume into the Mediterranean during 18Z 21-12Z 23 March. Its local PV maximum coincided with a weak surface cyclone west of Portugal (Fig. 101) that can also be identified in the IR image with a broad and fuzzy cloud structure in the warm sector
(Fig. 10k). The dust ejection into the Mediterranean is confirmed by the visible satellite image on 22 March (Fig. 11b). During 12Z 23-00Z 25 March wet deposition took place at Piz Zupó in qualitative agreement with the cloud structures in the IR images (see electronic supplement), the scattered precipitation signals recorded in the Piz Zupó area during this time period (Fig. 12), and the trajectory-based precipitation estimate (Fig. 9a). Wet deposition prior to arrival is low for the strongest part of the M3 phase, indicating that conditions were favourable for preserving this dust event at Piz Zupó.

\subsection{Large-scale flow imprints on dust transport}

The above analysis of the meteorological flow evolution during the October and March dust events demonstrates that there is no archetypal pattern which leads to dust events in the Alpine area. The enhanced trajectory analysis allowed for distinguishing dust events which were likely to be preserved in the glacier from those that probably did not reach Piz Zupó due to prior wet deposition, and to attribute a specific flow evolution to each dust transport event.

Remarkable similarities and differences between the considered phases of dust export are apparent. First, direct northward transport from the Sahara to the Alps occurred when a stratospheric PV streamer was stretching into northern Africa and induced anomalous southerly flow over the Mediterranean. In the October case, this streamer formed due to Rossby-wave breaking (see an example in Morgenstern and Davies, 1999), while in March during phase M3 a first streamer of type I (Appenzeller et al., 1996) broke up and formed a cut-off that remerged near Scotland to form a secondary streamer. This difference in the formation history of the two western Mediterranean PV streamers is noteworthy and illustrates the complexity and variability of meteorological processes that can lead to large-scale dust transport to Central Europe. This aspect is underlined by the dust transport phase M2 in March 2000, where several seemingly independent meteorological features cooperated in order to transport dust from the western Sahara within 9 days across the Capverde Islands and the Azores to $60^{\circ} \mathrm{N}$ and across Germany to Piz Zupó.

The importance of the upper-level flow configuration on dust export from the Sahara has already been noted by a number of studies (Prodi and Fea, 1978, 1979; Alpert and Ganor, 1993; Barkan et al., 2005). Notably, the PV streamer flow configuration is reminiscent of the typical precursor structure for heavy precipitation on the Alpine south-side, where quasi-stationary PV streamers extending over France into the western Mediterranean can direct large moisture fluxes along their eastern side towards the Alps (Massacand et al., 1998; Martius et al., 2006). From our study, it becomes evident that particularly elongated streamers which also reach into northern Africa can direct dry and dusty Saharan air masses towards the Alps. Similar atmospheric flow configurations 


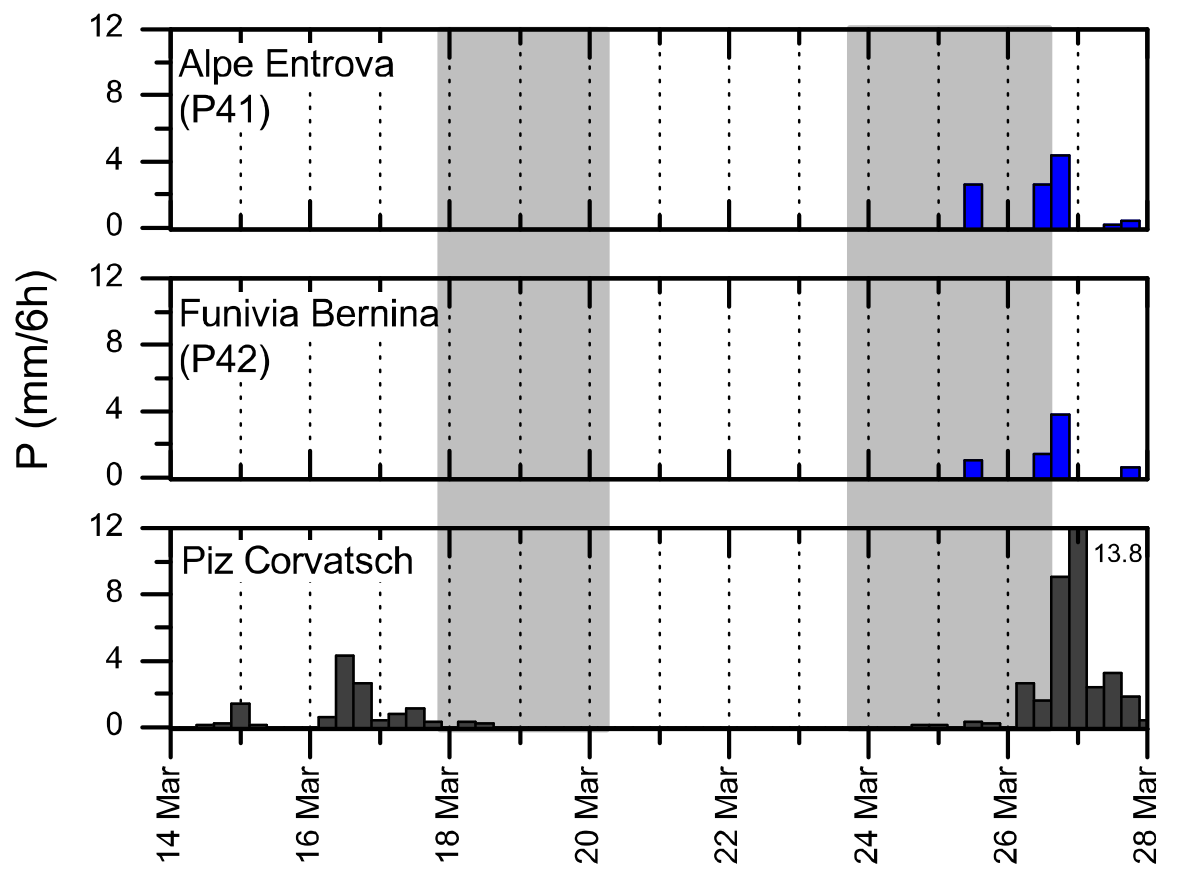

Fig. 12. As Fig. 7, but for 14-28 March 2000. Areas shaded in gray from left to right denote the dust phases M2 and M3 identified from the back-trajectory analysis.

including an upper-level PV streamer extending into the African subtropics and a southwest-northeast oriented jet in the middle troposphere may also play a role during tropicalextratropical interactions (Knippertz et al., 2003). Convective activity triggered near the right entry and left exit of the jet could further support uplift of desert dust and subsequent long-range transport in adjacent bands of moist cloudy and dry dusty air towards northerly directions (Figs. 8, 6e). In some cases, the northward transport of dust and moisture occurs almost simultaneously, as indicated by the severe flash flood event in Gondo on 13/14 October 2000 that was followed by the most prominent dust event recorded in the Piz Zupó ice core. Note however that this combined occurrence of heavy rain and Saharan dust in the southern Alps might be exceptional since (i) many PV streamers that produce heavy rain do not reach far enough into the desert to trigger the export of dust, (ii) not every southerly flow across the Mediterranean that carries Saharan dust is also advecting large amounts of moisture from the Mediterranean. It is therefore not possible to interpret the ice core's dust signal as a direct record of extreme precipitation, or vice versa.

\section{Contributions to the chemical signal in the ice core}

The chemical signal in the ice core potentially reflects contributions from the source area of dust, from different transport paths, and from differences in the deposition process. Applying again the extended back-trajectory methodology, we aim to disentangle the importance of the various contributors to the ice core chemistry.

An important source of information for this task are additional chemistry data at higher temporal resolution than provided by the ice core, for instance from aerosol or precipitation chemistry measurements. No chemical analyses of the precipitation near Piz Zupó are available for comparison. Instead, we rely on data from the literature which were acquired at other Alpine locations as a proxy for Piz Zupó. During February and March 2000, the Cloud and Aerosol Characterisation Experiment (CLACE-1) took place at the Jungfraujoch (JFJ) high alpine observatory $\left(46^{\circ} 32^{\prime} \mathrm{N}\right.$, $7^{\circ} 59^{\prime}$ E, $3580 \mathrm{~m}$ a.s.l., Fig. 1). During this campaign, several physical and chemical properties of aerosol were sampled during both dust phases M2 and M3 at very high temporal resolution. Besides scattering and absorption coefficient measurements, single-particle composition spectra were acquired (Hinz et al., 2005).

Back-trajectory analysis repeated for the JFJ revealed some differences in timing and magnitude of the dust events compared with Piz Zupó (not shown). At JFJ, the dust phases occurred slightly earlier than at Piz Zupó (Phase M2: 20Z 16-20Z 18 March from CLACE-1, 12Z 17-18Z 19 March from JFJ back-trajectories, phase M3: 03Z 2318Z 24 March from CLACE-1, 06Z 23-00Z 25 March from JFJ back-trajectories). Dust phase M2 experienced less prearrival wet deposition, and the M3 event was significantly stronger than at Piz Zupó. The CLACE-1 measurements thus 


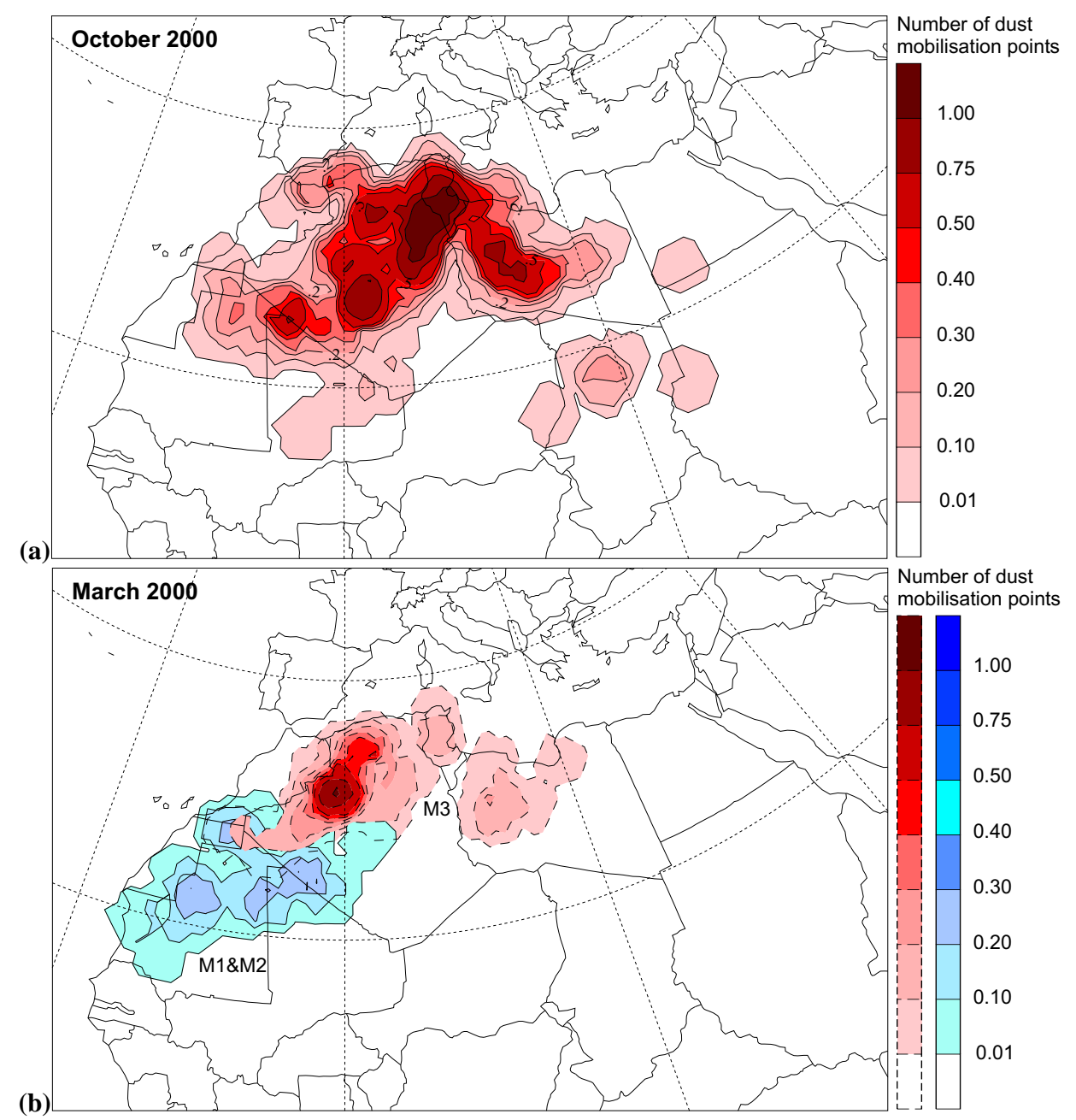

Fig. 13. Probability density functions of potential source regions of Saharan dust identified from objective selection criteria for the Saharan dust events recorded in the Piz Zupó ice core in (a) October and (b) March 2000. Scale in arbitrary units. See text for details.

provide some independent evidence for the chemical composition of the arriving dust and the results from our trajectory study. However, small-scale variability inherent to Saharan dust events in the Alpine area makes a detailed comparison between JFJ and Piz Zupó difficult. Therefore, we can only use the CLACE-1 data as a proxy information for the actual precipitation composition at Piz Zupó.

\subsection{Dust source region signal}

The enhanced back-trajectory method allowed for extraction of the locations where the mobilisation criteria as defined in Sect. 4.3 were fulfilled. Probability density functions of these potential uptake locations are interpreted as potential source areas of Saharan dust (Fig. 13). Uptake locations are only shown for air masses transported towards Piz Zupó, and for the mobilisation periods given in Table 1.

For the October 2000 event (Fig. 13a), the identified source regions are rather widely dispersed in the northern Sa- hara. Yet, two regions with increased potential mobilisation are apparent, one in Algeria along the axis of the previously mentioned mid-level jet, and one in western Libya. These northern mobilisation maxima together with the wider distribution of weaker sources indicate that although the mineralogy of soils in the northern Sahara dominates, dust mobilised previously further south may be mixed into the dust plume transported to the Alps. This could lead to a blurred chemical source region signal (Schütz and Sebert, 1987).

For the March 2000 events, dust source regions were identified separately for the dust phases M1, M2 and M3 (Fig. 13b). The first two phases exhibit dust sources in West Sahara, Mali, and Mauritania, while for the phase M3 source regions in Algeria and Libya dominate, which is indicative of the meteorological similarity to the October event.

In the Piz Zupó ice core record, large peaks in the concentration of $\mathrm{Ca}^{2+}$ mark the October and March dust events (Fig. 2). The $\mathrm{Ca}^{2+}$ concentration during the October event 
(a)

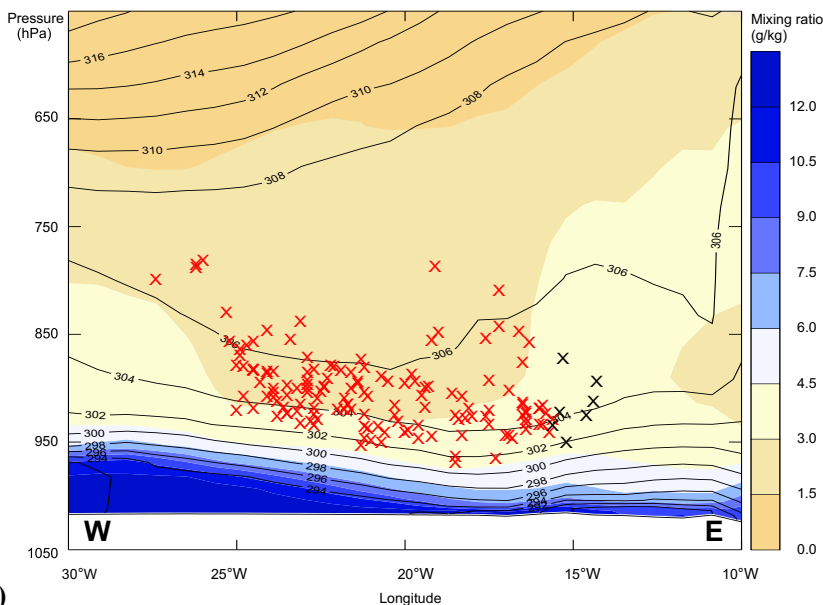

(b)

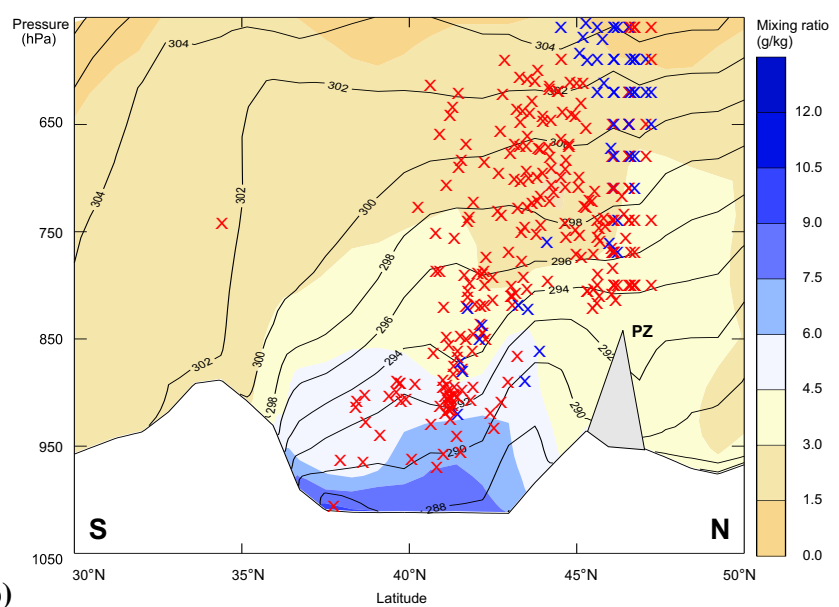

Fig. 14. Vertical cross-sections during the ejection of the dust plumes along the transects marked in Fig. 4b. (a) M2 (00Z 12 March) and (b) M3 (18Z 23 March). Shown are mixing ratio $\left(\mathrm{g} \mathrm{kg}^{-1}\right.$, shaded), potential temperature (contour interval $2 \mathrm{~K}$, contours), and crosses indicating the position of potentially dust-laden air parcels identified from the back-trajectory analysis. The vertical axis is given in pressure units; $800 \mathrm{hPa}$ correspond roughly to $1900 \mathrm{~m}$ a.s.l. and $500 \mathrm{hPa}$ to $5500 \mathrm{~m}$ a.s.l. The marine boundary layer top is expected near the strongest vertical gradient in mixing ratio.

is by far the largest signal during the 11-yr record. It covers about $0.20 \mathrm{~m}$ w.e. in the ice core. The section identified as the March event in the ice core shows two peaks in $\mathrm{Ca}^{2+}$ close to each other, a stronger one from 7.1-7.3 $\mathrm{m}$ w.e. and a smaller one from 7.0-7.1 m w.e. Soils in the northern Sahara are relatively rich (partly $>15 \%$ ) in calcite $\left(\mathrm{CaCO}_{3}\right)$, while towards the south concentrations decrease (Schütz and Sebert, 1987; Claquin et al., 1999). Accordingly, $\mathrm{Ca}^{2+}$ and calcite are widely used as tracers of Saharan dust events over Europe (Wagenbach and Geis, 1989; Schwikowski et al., 1995; Avila et al., 1997), and the high concentrations for the October and March events are in good agreement with the prominent northern Saharan dust source regions identified by the enhanced back-trajectory analysis.

Single-particle mass spectra measured during CLACE-1 support the shift in source regions between phase M1/M2 and M3. Hinz et al. (2005) found differences in the intensity ratios of nitrate, phosphate, sulfate, silicon, titanium, and iron and their oxides between 17/18 and 23 March. In particular, slightly higher class abundances of particles rich in iron oxides (particle class "mineral 2", Fig. 8 in Hinz et al., 2005) were noted on 23 March.

However, due to resuspension, the mineralogy of a mineral aerosol is not necessarily identical with the mineralogy of its source region (Schütz and Sebert, 1987; Claquin et al., 1999). Furthermore, changes in the mineralogical composition might occur during dust transport due to the preferential deposition of coarser particles or dissolution of calcite. This could in particular be the case for long transport paths, such as for phase M2. The analysis of rare earth elements, and the ${ }^{87} \mathrm{Sr} /{ }^{86} \mathrm{Sr}$ and ${ }^{143} \mathrm{Nd} /{ }^{144} \mathrm{Nd}$ combined isotope ratios could improve the identification of source regions, but so far very few such data are available from Alpine ice cores.

\subsection{Uptake of chemical species during transport}

Several chemical species which show extraordinarily high values in the Piz Zupó ice core for the two dust events (Sect. 3, Fig. 2) are unlikely to originate from the source region of the mineral aerosol. This includes typical sea spray components, such as $\mathrm{Na}^{+}, \mathrm{Cl}^{-}$, and partly $\mathrm{SO}_{4}^{2-}$, as well as MSA. In a laboratory study, Adams et al. (2005) showed that Saharan dust can effectively bind $\mathrm{SO}_{2}$, which later can be oxidised into $\mathrm{SO}_{4}^{2-}$. MSA is formed by photo-oxidation of dimethylsulfide (DMS), which is in turn released by marine phytoplankton near the ocean surface (Huebert et al., 2004). The chemical species $\mathrm{NH}_{4}^{+}, \mathrm{NO}_{3}^{-}$, and partly $\mathrm{SO}_{4}^{2-}$ are tracers for polluted air masses (Schwikowski et al., 1995; Jordan et al., 2003; Aymoz et al., 2004). Their strongest sources are in the marine or anthropogenically influenced BL.

Accordingly, these chemical components are most likely scavenged by the mineral aerosol somewhere along its transport path. Scavenging can take place in several ways: (i) Chemical components are contained in BL air masses that are transported to the glacier independently from the dust transport, where they then undergo scavenging during wet deposition. Such independent yet subsequent transport and deposition of dust and anthropogenic pollution has been reported recently for a valley in the French Alps (Aymoz et al., 2004). (ii) Chemical components are scavenged by the mineral aerosol particles along their path through the BL, and subsequently deposited at the glacier adsorbed onto the mineral aerosol. (iii) Chemical components are already contained in the air mass before dust mobilisation occurs, and scavenging takes place during mobilisation and transport. A combination of these processes may be possible as well. 


\subsubsection{Sea salt}

With respect to sea salt species, the ice core record shows only minor differences for the two dust events (Fig. 2), the exception being $\mathrm{Cl}^{-}$, which is much larger for the October than for the March event. The high concentrations of $\mathrm{NO}_{3}^{-}$ and $\mathrm{NH}_{4}^{+}$during March are also exceptional. Schwikowski et al. (1995) noted extraordinarily high scavenging efficiencies of $\mathrm{Cl}^{-}, \mathrm{NO}_{3}^{-}, \mathrm{SO}_{4}^{2-}$, and $\mathrm{NH}_{4}^{+}$during snow falls associated with Saharan dust at JFJ, probably due to increased riming. For TSP data from JFJ, Henning et al. (2003) note a general enhancement in the non-volatile nitrate fraction with increasing calcium concentrations due to reaction of gaseous $\mathrm{HNO}_{3}$ with $\mathrm{CaCO}_{3}$, but also some situations where small coarse nitrate fractions occur along with high $\mathrm{Ca}^{2+}$, namely during Saharan dust events. Further comparison of specific concentration measurements at JFJ with our ice core data is prohibited by the pronounced spatial variability inherent to Saharan dust events on scales of $\approx 10$ to $100 \mathrm{~km}$. Nevertheless, it seems plausible that during both dust events contact or mixing with marine BL air occurred, while during the March event in addition polluted air masses interacted with the dust plume somewhere along the transport path.

\subsubsection{MSA}

A different explanation is required for the MSA signal in the ice core. While for the March event a large MSA peak similar to that of the anthropogenic pollutants can be observed, MSA is virtually absent from the ice core record during October. The question arises as to what causes the difference in MSA between the two dust events. This issue is addressed by considering the potential source regions of MSA during the two dust events. Since MSA resides in the marine BL as an oxidation product of DMS, which is exclusively produced by certain phytoplankton species, we use chlorophyll $a$ concentrations at the sea surface obtained from remote sensing satellites as a proxy for the presence of MSA in the marine BL (Sect. 2.3).

Overlaying the chlo- $a$ maps with representative dust transport trajectories for the two dust events indicates potential for MSA uptake from areas of high phytoplankton concentrations (Fig. 4). During the week 7-14 October, areas of high concentration of chlo- $a$ are confined to the North Sea and upwelling areas off the African west coast (Fig. 4a). In these areas, concentrations of chlo- $a$ reach $3-10 \mathrm{mg} \mathrm{m}^{-3}$. A composite for the week from 13-20 March (Fig. 4b) shows a general southward shift of high phytoplankton concentration areas, and an intensified maximum off the African west coast. Importantly, the western Mediterranean now exhibits a centre of moderate concentration of chlo- $a$ between $0.3-1.0 \mathrm{mg} \mathrm{m}^{-3}$, compared to less than $0.1 \mathrm{mg} \mathrm{m}^{-3}$ in October. This is an indication of the spring phytoplankton bloom that usually takes place in this area during March and April (Bosc et al., 2004).
Most other areas of the Mediterranean show low concentrations of chlo- $a$ at that time of the year $\left(<0.2 \mathrm{mg} \mathrm{m}^{-3}\right)$.

Time-series of vertical cross-sections as indicated in Fig. $4 \mathrm{~b}$ were inspected for the passage of the dust plumes across the potential source regions of MSA, and in order to identify the likelihood of an interaction between the dust plume and the potentially MSA-laden marine BL air masses (Fig. 14). During the dust phase M2, the extended backtrajectory analysis indicates that the dust-laden air masses offshore the African west coast were above the marine BL (Fig. 14a). The marine BL top is defined here by the strongest vertical gradient of water vapour mixing ratio. The dry Saharan air masses continuously remained above the very shallow marine BL and subsequently were slowly lifted during their northward transport (Sect. 5.2). While crossing the potential source areas of MSA in the North Sea, the dust plume was still above the marine BL $(850-600 \mathrm{hPa}$, not shown). However, during the dust phase M3, a different picture emerges (Fig. 14b). Here, the marine BL over the western Mediterranean is less clearly defined than off the West African coast. Some dust parcels appear to travel within moist areas of the marine BL. The air masses approach Piz Zupó directly across the chlo- $a$ maximum in the Gulf of Genova (Fig. 4b). Rapid dust ejection governed by a mid-tropospheric jet structure similar to the October event possibly triggered convection near the jet's left exit region during 23 March (see electronic supplement: http://www. atmos-chem-phys.net/6/667/acp-6-667-sp.zip), thereby enhancing the likelyhood of mixing between mineral aerosol and marine BL air. Hence, our back-trajectory analysis indicates that the large MSA peak in the ice core record for the March event was caused by aerosol scavenging while the dust plume M3 interacted with the marine BL air during its passage over the spring maximum in the phytoplankton bloom in the western Mediterranean.

Single particle analysis during the CLACE- 1 campaign at JFJ showed an interesting shift in chemical composition from 23 to 24 March (Hinz et al., 2005, Figs. 8, 10). On 23 March, particles reflecting an internal mixture of carbon and mineral components were found, albeit in low concentrations. These indicate interaction of carbon-containing particles with mineral particles. Towards 24 March, incidence abundances of ammonium, sulfate, nitrate, and carbon increased while mineral components showed a decrease. These findings from Hinz et al. (2005) corroborate that phase M3 brought chemically altered mineral aerosol particles, which had been exposed to BL air both over the Mediterranean and northern Italy into the Alpine area. Back-trajectory analysis confirmed that the transport of Saharan dust at JFJ quickly ceased after 06Z 24 March (not shown). The transport path of dust-laden air parcels suggests that pollution sources near Genova or Milano contributed to the anthropogenic signals at Piz Zupó.

Vertical cross-sections for the October event (not shown) show similar potential for interaction with the marine BL over the Mediterranean as during March. High 
concentrations of sea spray components (e.g. $\mathrm{Cl}^{-}$) in the ice core chemistry confirm that such interaction occurred (Fig. 2). However, as can be inferred from Fig. 4a, in October concentrations of chlo- $a$ were substantially lower in the western Mediterranean than during March. This would also be expected from the phytoplankton seasonality in that area (Bosc et al., 2004). Therefore, the most likely explanation for the absence of MSA in October is that concentrations of MSA in the marine BL were much smaller than in March.

\section{Discussion of the applied methodology}

An assessment of the reliability and soundness of the new methodology applied here is required in order to draw significant conclusions from this study, in particular as it combines data from different sources and with different spatial and temporal scales. The ice core from Piz Zupó represents a point sample that integrates over time scales of a few days. Back-trajectory calculations, on the other hand, while having a higher temporal resolution, are limited by their spatial accuracy and representativeness, and are not straightforwardly related to a point sample. Some critical aspects related to the methodology are elucidated below.

The spatial uncertainty due to uncertainties in the wind fields and calculation techniques is a central issue of backtrajectory methods. Past dust transport studies mostly relied on single back-trajectories, typically at different vertical levels (Schwikowski et al., 1995; Avila et al., 1997; Ansmann et al., 2003). In this study, spatial uncertainty is taken into account by calculating ensembles of trajectories for each time step (Sect. 4.1), rather than considering single starting points. However, spatial uncertainty increases with the integration time of backward trajectories. The spatial spread of the ensemble gives an indication of the coherence of the flow and hence the reliability of e.g. a potential dust source region. The 10-day calculation time is therefore a compromise between the reliability of the calculations and the ability of the method to capture all relevant dust mobilisations. Note, however, that this method cannot account for analysis errors in the wind field, e.g. due to sparse data coverage.

Sufficiently high wind velocity near the surface is a wellestablished criterion for dust mobilisation. Studies by Shao and Leslie (1997) and Schoenfeldt and von Loewis (2003) indicate that if the $10 \mathrm{~m}$ wind speed exceeds $10 \mathrm{~m} \mathrm{~s}^{-1}$, wind shear near the surface becomes sufficiently strong to mobilise significant amounts of dust. The wind speed considered by our methodology is taken at the position of an air parcel rather than at a fixed height of $10 \mathrm{~m}$ above ground, hence our mobilisation velocities may be biased high. However, observing the movement of Saharan dust over land and sea from satellites, Koren and Kaufman (2004) found velocities of 10 to $13 \mathrm{~m} \mathrm{~s}^{-1}$ for whole dust plumes.

Our assumption for the boundary layer height (BLH) is well in the range typically observed and modelled for the Sa- hara. In a sensitivity study of the TOMS aerosol index, Mahowald and Dufresne (2004) found boundary layer heights of around $1 \mathrm{~km}$ in January and larger than $3 \mathrm{~km}$ in July. As we consider the months March and October only, a BLH of $\approx 1.9 \mathrm{~km}$ a.s.l. is a reasonable assumption. However, we do not account for the pronounced daily cycle in BLH in desert areas, with nighttime values as low as $200 \mathrm{~m}$ (Mahowald and Dufresne, 2004). During the strong wind conditions required for the mobilisation of dust, however, nighttime BLHs should be larger than the low BLHs produced by radiative cooling in steady air. In a number of LIDAR studies, the height of dust plumes leaving the African continent was typically observed to be at or above $1.5 \mathrm{~km}$ (Hamonou et al., 1999; Mattis et al., 2002; Leon et al., 2003). Off the African coast, dust layers were in general multi-layered, and reached up to $5 \mathrm{~km}$ above ground. Hence, long-range transport seems to begin at around $1.5 \mathrm{~km}$ height above ground. Taking into account the underlying orography, our assumed BLH complies well with these observations.

Soil moisture is a factor that can be important for dust mobilisation (Ravi et al., 2004), but has not been considered in this study. Seasonal or short-term changes in precipitation may render some regions incapable to emit dust, while others may become more productive than in the annual mean. Also, different soil properties such as suspendibility have a large influence on the amount of dust emitted from a certain area, and lead to well-known "hot-spots" of dust emission (Goudie and Middleton, 2001; Koren and Kaufman, 2004). In addition, seasonality in vegetation cover is not accounted for, as the data set by DeFries and Townshend (1994) was generated from one year of averaged NDVI (normalised difference vegetation index) satellite data only. The largest part of our potential source area is however bare soil and should not show significant seasonal vegetation changes.

Physical properties of the dust itself, such as size spectra, have not been taken into account here. Size spectra are important for the dry deposition of heavier particles, and the ageing of mineral aerosol during transport. Typical settling velocities of long-range transported mineral aerosol are in the range of $0.001-0.02 \mathrm{~m} \mathrm{~s}^{-1}$, but may be significantly higher for large particles (Duce et al., 1991). Hence, for longer transportation times, such as during phase M1 and M2, dry deposition of larger particles is likely to be more relevant than for the short transport paths observed during phase M3 and the October event. These influences are only taken into account in a very qualitative way in this study.

Wet deposition of mineral aerosol at Piz Zupó was identified with a relative humidity criterion, and confirmed by nearby precipitation with respect to timing. However, undisputable evidence that scavenging of mineral aerosol actually is taking place would require additional information. Aerosol measurements from the nearby JFJ observatory provided valuable but limited evidence, as the two locations may experience a different timing of the dust events. In addition, as noted above, high aerosol concentrations are a 
necessary but insufficient criterion for the formation of dust layers in snow, as precipitation is needed for efficient deposition (Osada et al., 2004). Finally, only detailed analyses of precipitation chemistry could provide insight into the wet removal process that is actually taking place during a dust event (Schwikowski et al., 1995). Given such detailed data were available, they would allow for an interesting validation study of our back-trajectory methodology.

The qualitative methodology presented here can be considered as a first-order Lagrangian dust transport model. It could be extended to a full dust transport model by including parameterisations of further dust-related processes, in particular convection, coagulation, and gravitational settling of dust particles. Currently, however, it is essential that all estimates of source regions and transport pathways of dust in this study be interpreted as "potential" source regions and "estimates" for transport pathways and processes along them. Future applications of such a refined Lagrangian transport model could include modelling the transport of other aerosols, for instance from urban plumes, or biogenic substances, such as pollen.

\section{Conclusions}

In an ice core recovered from the high-accumulation glacial site Piz Zupó in the Swiss Alps, two large dust events were identified that occurred in March and October 2000. The two dust events were characterised by pronounced changes in chemical composition compared to other sections of the ice core. A particularly noteworthy chemical difference existed also between the two dust events, namely exceptionally high concentrations of methanesulphonic acid (MSA) in the M3 case. The two identified periods were studied indepth by means of a new method based on three-dimensional kinematic back-trajectories combined with objective selection criteria. The aims of this study were (i) to understand how the mobilisation area, transport pathway, and depositional conditions of the Saharan dust contributed to the chemical signatures observed in the ice core, and (ii) to investigate if different evolutions of the synoptic flow can lead to similar occurrences of dust layers in an Alpine ice core.

For October 2000, the extended back-trajectory analysis indicated that intense dust mobilisation occurred along a region stretching from northern Mauritania across Algeria into Tunesia during 11-15 October. Subsequently, mobilised dust was rapidly transported across the Mediterranean towards the Alps from southerly directions, and deposited at Piz Zupó during the following 2-3 days (Table 1).

In March 2000, three phases of Saharan dust mobilisation and deposition at Piz Zupó were identified. During the first minor phase probably all dust rained out before arriving at the glacier. During the second phase, dust was transported during 9 days along a rather exceptional pathway across the eastern North Atlantic, approaching the Alps from northerly directions. Only a few days later a third dust trans- port phase occurred, bringing Saharan air masses directly from southerly directions across the Mediterranean towards the Alps, similar to the October event (Table 1).

Our main conclusions from the analysis of these two dust events are as follows:

1. Major differences in the chemical signature of the two dust events preserved in the ice core were shown to be related to different process histories during transport rather than source regions. High concentrations of MSA in March 2000 were most likely caused by aerosol scavenging during the passage of the dust through the marine boundary layer over areas of high phytoplankton productivity in the western Mediterranean. In October 2000, despite a similar transport pathway, the potential for MSA scavenging was reduced due to seasonally low phytoplankton activity. In March, pollution sources that were encountered during the transport probably led to highly enhanced concentrations of $\mathrm{NH}_{4}^{+}$and $\mathrm{NO}_{3}^{-}$.

2. The transport patterns of dust from the Saharan desert to the Swiss Alps can vary substantially from case to case. Even within a single large event identified in the ice core, they may change drastically from one day to another. It is thus not possible to identify one single meteorological situation which is typically associated with the transport of dust towards central Europe. This underlines the variability of dust transport into the Alpine region. Particularly strong dust events recorded at our study site and rapid transfer of Saharan dust to the Alps can be induced by the presence of large upperlevel PV streamers that reach to northern Africa. In many cases, this flow configuration can also be associated with heavy precipitation at the Alpine southside, and hence favour the wet deposition of dust.

3. Potential source regions of dust were identified in the Algerian and Libyan deserts in the case of dust transport directly from the south, while mobilisation areas for transport across the Atlantic were centrered around Mauritania. It is currently not possible to clearly corroborate the source area identification from the chemical composition of the dust, as no definite chemical tracer is readily available. Visible satellite imagery however suggests that the potential mobilisation regions identified from the Lagrangian analysis are generally in good agreement with the actual source regions of dust.

4. The novel dust-transport analysis based on backtrajectories and objective criteria for dust mobilisation and deposition successfully captured the transport pathways of Saharan dust, and established a direct link between atmospheric circulation features and the chemical signal in the ice core. Dust events having lost most of their dust load due to wet deposition before reaching the arrival site, but which erroneously would have been 
identified by examining back-trajectories in a conventional way, could clearly be rejected with the methodology applied here. Additional observational evidence, such as satellite images, air chemistry measurements, and precipitation data, proved to be very valuable in order to back up the results of the advanced trajectory study.

From our study, it becomes evident that in order to interpret the complex chemical signal of dust deposited in an ice core it is essential to examine the full transport sequence of dust mobilisation, transport, and deposition. The new backtrajectory methodology, which incorporates additional meteorological information combined with further observational evidence proved to be very valuable for this kind of analysis.

Acknowledgements. Chlorophyll $a$ data were provided by the SeaWiFS Project, NASA/Goddard Space Flight Center and Orbimage. ARPA Lombardia is acknowledged for access to the precipitation data. MeteoSwiss is acknowledged for access to the ECMWF data and the satellite imagery. This project was partly funded by the Swiss NCCR Climate programme.

Edited by: U. Pöschl

\section{References}

Adams, J. W., Rodriguez, D., and Cox, R. A.: The uptake of $\mathrm{SO}_{2}$ on Saharan dust: a flow tube study, Atmos. Chem. Phys., 5, 26792689, 2005.

Alpert, P. and Ganor, E.: A jet-stream associated heavy dust storm in the western Mediterranean, J. Geophys. Res., 98, 7339-7349, 1993.

Ansmann, A., Bösenberg, J., Chaikovsky, A., Comerón, A., Eckhardt, S., Eixmann, R., Freudenthaler, V., Ginoux, P., Komguem, L., Linné, H., Márquez, M. A. L., Matthias, V., Mattis, I., Mitev, V., Müller, D., Music, S., Nickovic, S., Pelon, J., Sauvage, L., Sobolewsky, P., Srivastava, M. K., Stohl, A., Torres, O., Vaughan, G., Wandinger, U., and Wiegner, M.: Long-range transport of Saharan dust to northern Europe: The 11-16 October 2001 outbreak observed with EARLINET, J. Geophys. Res., 108, 4783, doi:10.1029/2003JD003 757, 2003.

Appenzeller, C., Davies, H. C., and Norton, W. A.: Fragmentation of stratospheric intrusions, J. Geophys. Res., 101, 1435-1456, 1996.

Avila, A., Queralt-Mitjans, I., and Alarcon, M.: Mineralogical composition of African dust delivered by red rains over northeastern Spain, J. Geophys. Res., 102, 21 977-21 996, 1997.

Aymoz, G., Jaffrezo, J.-L., Jacob, V., Colomb, A., and George, C.: Evolution of organic and inorganic components of aerosol during a Saharan dust episode observed in the French Alps, Atmos. Chem. Phys., 4, 2499-2512, 2004.

Barkan, J., Alpert, P., Kutiel, H., and Kishcha, P.: Synoptics of dust transportation days from Africa toward Italy and central Europe, J. Geophys. Res., 110, D07208, 2005.

Bergametti, G., Gomes, L., Coudegaussen, G., Rognon, P., and le Coustumer, M.-N.: African dust observed over Canary Islands - Source-regions identification and transport pattern for some summer situations, J. Geophys. Res., 94, 14 855-14 864, 1989.
Bonasoni, P., Cristofanelli, P., Calzolari, F., Bonafè, U., Evangelisti, F., Stohl, A., Zauli, S., van Dingenen, R., Colombo, T., and Balkanski, Y.: Aerosol-ozone correlations during dust transport episodes, Atmos. Chem. Phys., 4, 1201-1215, 2004.

Bosc, E., Bricaud, A., and Antoine, D.: Seasonal and interannual variability in algal biomass and primary production in the Mediterranean Sea, as derived from 4 years of SeaWiFS observations, Global Biogeochem. Cycles, 18, GB1005, doi:10.1029/2003GB002034, 2004.

Bricaud, A., Bosc, E., and Antoine, D.: Algal biomass and sea surface temperature in the Mediterranean Basin: Intercomparison of data from various satellite sensors, and implications for primary production estimates, Remote Sens. Environ., 81, 163-178, 2002.

Claquin, T., Schulz, M., and Balkanski, Y. J.: Modeling the mineralogy of atmospheric dust sources, J. Geophys. Res., 104, $22243-$ 22 256, 1999.

Collaud Coen, M., Weingartner, E., Schaub, D., Hueglin, C., Corrigan, C., Henning, S., Schwikowski, M., and Baltensperger, U.: Saharan dust events at the Jungfraujoch: detection by wavelength dependence of the single scattering albedo and first climatology analysis, Atmos. Chem. Phys., 4, 2465-2480, 2004.

DeFries, R. S. and Townshend, J. R. G.: NDVI-derived land cover classification at global scales, Int. J. Remote Sensing, 15, 35673586, 1994.

Duce, R., Liss, P. S., Merrill, J. T., Atlas, E. L., Buatt-Ménard, P., Hicks, B. B., Miller, J. M., Prospero, J. M., Arimoto, R., Church, T. M., Ellis, W., Galloway, J. N., Hansen, L., Jickells, T. D., Knap, A. H., Reinhardt, K. H., Schneider, B., Soudine, A., Tokos, J. J., Tsunogai, S., Wollast, R., and Zhou, M.: The atmospheric input of trace gas species to the world ocean, Global Biogeochem. Cycles, 5, 193-259, 1991.

Eichler, A., Schwikowski, M., Gäggeler, H. W., Furrer, V., Synal, H.-A., Beer, J., Saurer, M., and Funk, M.: Glaciochemical dating of an ice core from upper Grenzgletscher (4200 m a.s.l), J. Glaciol., 46, 507-515, 2000.

Franzén, L. G., Hjelmroos, M., Kållberg, P., Rapp, A., Mattsson, J. O., and Brorström-Lundén, E.: The Saharan dust episode of south and central Europe, and northern Scandinavia, March 1991, Weather, 50, 313-318, 1995.

Goudie, A. S. and Middleton, N. J.: Saharan dust storms: nature and consequences, Earth-Sci. Rev., 56, 179-204, 2001.

Hamonou, E., Chazette, P., Balis, D., Dulac, F., Schneider, X., Galani, E., Ancellet, G., and Papayannis, A.: Characterization of the vertical structure of Saharan dust export to the Mediterranean basin, J. Geophys. Res., 104, 22 257-22 270, 1999.

Henning, S., Weingartner, E., Schwikowski, M., Gäggeler, H. W., Gehrig, R., Hinz, K.-P., Trimborn, A., Spengler, B., and Baltensperger, U.: Seasonal variation of water-soluble ions of the aerosol at the high-alpine site Jungfraujoch (3580 $\mathrm{m}$ asl), J. Geophys. Res., 108, 4030, doi:10.1029/2002JD002439, 2003.

Hinz, K.-P., Trimborn, A., Weingartner, E., Henning, S., Baltensperger, U., and Spengler, B.: Aerosol single particle composition at the Jungfraujoch, J. Aerosol Sci., 36, 123-145, 2005.

Huebert, B. J., Blomquist, B. W., Hare, J. E., Fairall, C. W., Johnson, J. E., and Bates, T. S.: Measurement of the air-sea DMS flux and transfer velocity using eddy correlation, Geophys. Res. Lett., 31, L23113, doi:10.1029/2004GL021567, 2004.

Jones, C., Mahowald, N., and Luo, C.: The role of easterly waves 
on African desert dust transport, J. Clim., 16, 3617-3628, 2003. Jordan, C. E., Dibb, J. E., Anderson, B. E., and Fuelberg, H. E.: Uptake of nitrate and sulfate on dust aerosols during TRACE-P, J. Geophys. Res., 108, 8817, doi:10.1029/2002JD003 101, 2003.

Knippertz, P., Fink, A. H., Reiner, A., and Speth, P.: Three late summer/early autumn cases of tropical-extratropical interactions causing precipitation in northwest Africa, Mon. Wea. Rev., 131, $116-135,2003$.

Koren, I. and Kaufman, Y. J.: Direct wind measurements of Saharan dust events from Terra and Aqua satellites, Geophys. Res. Lett., 31, L06122, doi:10.1029/2003GL019338, 2004.

Kornexl, B. E., Gehre, M., Hofling, R., and Werner, R. A.: On-line delta O-18 measurement of organic and inorganic substances, Rapid Comm. Mass Spectr., 13, 1685-1693, 1999.

Leon, J.-F., Tanre, D., Pelon, J., Kaufman, Y. J., Haywood, J. M., and Chatenet, B.: Profiling of a Saharan dust outbreak based on a synergy between active and passive remote sensing, J. Geophys. Res., 108, 8575, doi:10.1029/2002JD002774, 2003.

Mahowald, N. M. and Dufresne, J.-L.: Sensitivity of TOMS aerosol index to boundary layer height: Implications for detection of mineral aerosol sources, Geophys. Res. Lett., 31, L03103, doi:10.1029/2003GL018865, 2004.

Martius, O., Zenklusen, E., Schwierz, C., and Davies, H. C.: Episodes of Alpine heavy precipitation with an overlying elongated stratospheric intrusion: A Climatology, Int. J. Clim., in press, doi:10.1002/JOC.1295, 2006.

Massacand, A. C., Wernli, H., and Davies, H. C.: Heavy precipitation on the Alpine southside: An upper-level precursor, Geophys. Res. Lett., 25, 1435-1438, 1998.

Mattis, I., Ansmann, A., Mueller, D., Wandinger, U., and Althausen, D.: Dual-wavelength Raman lidar observations of the extinction-to-backscatter ratio of Saharan dust, Geophys. Res. Lett., 20, 20, doi:10.1029/2002GL014721, 2002.

Morgenstern, O. and Davies, H. C.: Disruption of an upper-level PV-streamer by orographic and cloud-diabatic effects, Contr. Atmos. Phys., 72, 173-186, 1999.

Moulin, C., Lambert, C. E., Dayan, U., Masson, V., Ramonet, M., Bousquet, P., Lagrand, M., Balkanski, Y. J., Guelle, W., Marticorean, B., Bergametti, G., and Dulac, F.: Satellite climatology of African dust transport in the Mediterranean atmosphere, J. Geophys. Res., 103, 13 137-13 144, 1998.

O'Dowd, C. D., Facchini, M. C., Cavalli, F., Ceburnis, D., Mircea, M., Decesari, S., Fuzzi, S., Yoon, Y. J., and Putaud, J.-P.: Biogenically driven organic contribution to marine aerosol, Nature, 431, 676-680, 2004.

O'Reilly, J. E., Maritorena, S. Mitchell, B. G., Siegel, D. A., Carder, K. L., Garver, S. A., Kahru, M., and McClain, C.: Ocean color chlorophyll algorithms for SeaWiFS, J. Geophys. Res., 103, 24 937-24 953, 1998.

Osada, K., Iida, H., Kido, M., Matsunaga, K., and Iwasaka, Y.: Mineral dust layers in snow at Mount Tateyama, Central Japan: formation processes and characteristics, Tellus, 56B, 382-392, 2004.

Papayannis, A., Balis, D., Amiridis, V., Chourdakis, G., Tsaknakis, G., Zerefos, C., Castanho, A. D. A., Nickovic, S., Kazadzis, S., and Grabowski, J.: Measurements of Saharan dust aerosols over the Eastern Mediterranean using elastic backscatter-Raman lidar, spectrophotometric and satellite observations in the frame of the EARLINET project, Atmos. Chem. Phys., 5, 2065-2079, 2005.
Preunkert, S., Wagenbach, D., Legrand, M., and Vincent, C.: Col du Dme (Mt Blanc Massif, French Alps) suitability for ice-core studies in relation with past atmospheric chemistry over Europe, Tellus, 52B, 993-1012, 2000.

Prodi, F. and Fea, G.: Transport and Deposition of Saharan dust over Alps, Proc. 15. Intern. Tag. f. Alpine Meteor., Grindelwald, pp. 179-182, 1978.

Prodi, F. and Fea, G.: A case of transport and deposition of Saharan dust over the Italian peninsula and southern Europe, J. Geophys. Res., 84, 6951-6960, 1979.

Prospero, J. M. and Lamb, P. J.: African droughts and dust transport to the Caribbean: Climate change implications, Science, 302, 1024-1027, 2003.

Ravi, S., D’Odrioco, P., Over, T. M., and Zobeck, T. M.: On the effect of air humidity on soil susceptibility to wind erosion: The case of air-dry soils, Geophys. Res. Lett., 31, L09501, doi:10.1029/2004GL019485, 2004

Ryall, D. B., Derwent, R. G., Manning, A. J., Redington, A. L., Corden, J., Millington, W., Simmonds, P. G., O'Dotherty, S., Carslaw, N., and Fuller, G. W.: The origin of high particulate concentrations over the United Kingdom, March 2000, Atmos. Environ., 36, 1363-1378, 2002.

Saurer, M., Robertson, I., Siegwolf, R., and Leuenberger, M.: Oxygen isotope analysis of cellulose: An interlaboratory comparison, Analyt. Chem., 70, 2074-2080, 1998.

Schoenfeldt, H.-J. and von Loewis, S.: Turbulence-driven saltation in the atmospheric surface layer, Meteorol. Z., 12, 257-268, 2003.

Schütz, L. and Sebert, M.: Mineral aerosols and source identification, J. Aerosol Sci., 18, 1-10, 1987.

Schwikowski, M., Seibert, P., Baltensperger, U., and Gäggeler, H. W.: A study of an outstanding Saharan dust event at the high-alpine site Jungfraujoch, Switzerland, Atmos. Environ., 15, 1829-1842, 1995.

Shao, Y. and Leslie, L. M.: Wind erosion prediction over the Australian continent, J. Geophys. Res., 102, 30 091-30 105, 1997.

Simmons, A. J. and Gibson, J. K.: The ERA-40 Project Plan, ERA40 Project Report Series No.1, ECMWF, Shinfield Park, Reading UK, 2000.

Tegen, I. and Fung, I.: Modeling of mineral dust in the atmosphere: Sources, transport, and optical thickness, J. Geophys. Res., 99, 22 897-22 914, 1994

Wagenbach, D. and Geis, K.: The mineral dust record in a high altitude Alpine glacier (Colle Gnifetti, Swiss Alps), in: Paleoclimatology and Paleometeorology: Modern and Past Patterns of Global Atmospheric Transport, edited by: Leinen, M. and Sarnthein, M., Kluwer Academic Publishers, p. 543-564, 1989.

Wernli, H. and Davies, H. C.: A Lagrangian-based analysis of extratropical cyclones. I: The method and some applications, Q. J. Roy. Meteor. Soc., 123, 467-489, 1997.

Wernli, H.: A Lagrangian-based analysis of extratropical cyclones. II: A detailed case-study, Q. J. Roy. Meteor. Soc., 123, 16771706, 1997. 